\title{
Why were the UK and USA unprepared for the COVID-19 pandemic? The systemic weaknesses of neoliberalism: a comparison between the UK, USA, Germany, and South Korea
}

\author{
Timothy I. Mellish¹, Natalie J. Luzmore², and Ahmed Ashfaque Shahbaz ${ }^{3}$
}

"Gentlemen, it is the microbes who will have the last word."

(Louis Pasteur)

\begin{abstract}
Pandemics historically have killed as many people as the wars that have beset this world, yet the resources committed to pandemic prevention and response are a fraction of the resources we commit to security. This paper examines the COVID-19 pandemic of 2020 by analysing the preparedness and responses of the UK, the USA, Germany, and South Korea. We will evidence that the UK and USA lacked the levels of preparedness that global health reports indicated, and that their responses were diametrically opposite of those of Germany and South Korea. We argue that decades of deregulation and privatization due to neoliberal, free-market economics by the UK and USA led to the Great Recession of 2008. This, in turn, led to economic collapse and austerity (increased neoliberalism), which negatively impacted investment in healthcare in the UK and USA. This resulted in very different levels of preparedness and responses by the four countries under the microscope.
\end{abstract}

Keywords: COVID-19, healthcare, preparedness, neoliberalism, politics, governance

\section{Introduction}

Pandemics historically have killed as many people as the wars that have beset this world, yet the resources committed to pandemic prevention and response are a fraction of the resources we commit to security (GHRF Commission, 2016). Most natural disasters are limited by geography, whereas the COVID-19 crisis, by contrast, has the whole planet in its grip. Natural disasters usually only affect localised communities in vulnerable geographic locations, however this crisis has victimised the world over. Like other pandemics, it will go down in history as a once-in-a-lifetime experience for the majority of global citizens alive today; albeit one or two remarkable exceptions - the Italian miracles of 101-year-old 'Mr P' and 104-year-old Ada Zanusso, who have both recovered from COVID-19 infections and who have lived through many pandemics and global disasters (Ioannidis, 2020; Porterfield, 2020; Winterburn, 2020). The International Monetary Fund calls it a "rare disaster" and states "this is a crisis like no other" (Gopinath, 2020).

At the time of publication, much has already been written on COVID-19, the majority being scientific or medical. In contrast, as fledgling political scientists, the authors have combined their International Business, International Relations, History, Politics, and International Law studies to write a paper that seeks to discuss the political, economic, and social impact of COVID-19. We looked with horror at the lack of readiness of the UK, which was in contrast to the responses of Germany and South Korea. It would be remiss of 
us not to include the USA as our research uncovered relevant and meaningful discourse in respect of the preparedness and response of the USA. We acknowledge and thank Professor Bülent Gökay for his support and guidance, for without it, this paper would not have been written.

\section{A “Black Swan" event}

Before moving to the main body of this paper, we believe it is essential to comment on whether COVID-19 is a "Black Swan" event; something that is unexpected or could not be predicted. Many commentators, scholars, writers, and political pundits are, at present, questioning whether COVID-19 can be categorised as an event that simply could not have been predicted.

In his seminal book, The Black Swan: The Impact of the Highly Improbable, Nassim Nicholas Taleb (2008) defines a "Black Swan" event. Taleb writes:

Before the discovery of Australia, people in the old world were convinced that all swans were white, an unassailable belief as it seemed completely confirmed by empirical evidence. The sighting of the first black swan might have been an interesting surprise for a few ethnologists, but that is not where the significance of the story lies. It illustrates a severe limitation to our learning from observations or experience and the fragility of our knowledge. One single observation can invalidate a general statement derived from millennia of confirmatory sightings of white swans. All you need is one single (and, I am told, quite ugly) black bird.

(Taleb, 20o8, Prologue) Taleb defines a "Black Swan" event as "an outlier, as it lies outside the realm of regular expectations because nothing in the past can convincingly point to its possibility. Second, it carries an extreme impact (unlike the bird). Third, in spite of its outlier status, human nature makes us concoct explanations for its occurrence after the fact, making it explainable and predictable" (Taleb, 2008, Prologue). This triplet of rarity, extreme impact and retrospective predictability can explain almost everything in our world, spanning ideas, religions, cults, and politics, to elements of our personal lives. If an event has low predictability, yet conversely has an extreme impact, then we can explain away the extreme impact and reduce our response to the event as a reaction rather than a planned process. As noted above, some writers or commentators argue or suggest that COVID-19 is different from other political and economic crises in that it is a "Black Swan" event, one that is unexpected and unpredicted and, therefore, is not possible to plan for a response.

Our position is that COVID-19 was only unpredictable in terms of the unexpected timing of the pandemic; in this respect, COVID-19 is like any other previous pandemic. However, we argue that COVID-19 is not a "Black Swan" event in that influenza pandemics are the subject of much discourse, with extensive and comprehensive planning amongst state and non-state actors, academics, health, medical, and scientific planners of national governments. Furthermore, as we will evidence, there have been many influenza pandemics or derivatives of them over the last century, with the most recent being in 2009. We argue that the timing of COVID-19 should be separated from the event itself; the timing and the event itself are not mutually inclusive but rather mutually exclusive.

However, as a precursor to a more detailed analysis of governmental planning and published documentation, an example goes back 12 years to 2008 with the UK Cabinet Office publishing the annual UK National Risk Assessment. This document sets out the government's "assessment of the likelihood and potential impact of a range of different risks that may directly affect the UK, as promised in the National Security Strategy". The National Risk Assessment "assesses the impact and likelihood of the major risks, both 


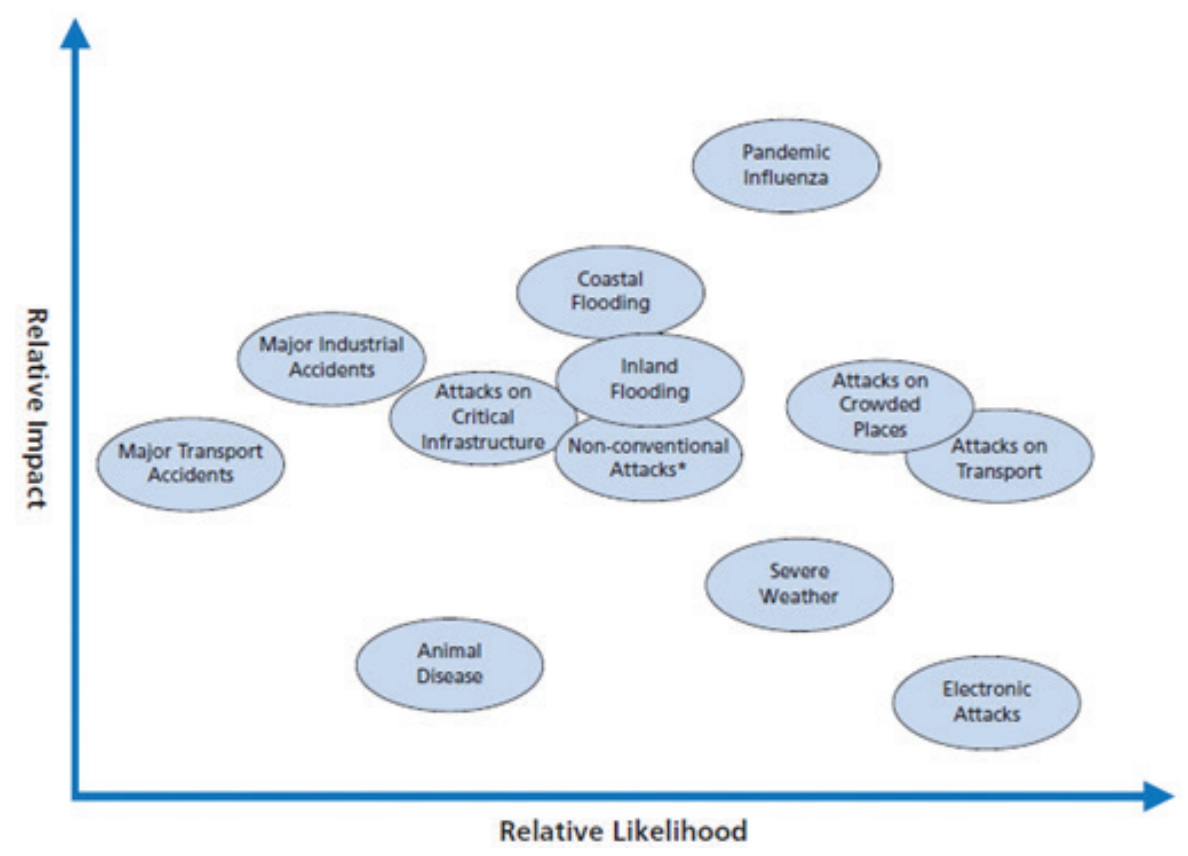

Figure 1 An illustration of the high consequence risks facing the United Kingdom.

Source: UK Cabinet Office, 2008.

hazards and threats, that the country could face over five years, enabling prioritization of the UK's planning for emergencies" (UK Cabinet Office, 2008). Page five of this publication has a diagram of a risk that would have the highest impact on the UK, that being an influenza pandemic (see Figure 1). Many other multiple high-level UK Government documents between 2004 and 2017 articulate the potential risk of an influenza pandemic and have put in place detailed plans, strategies, and tactics to deal with such an emerging pandemic.

From a global perspective, the Commission on Global Health Risk Framework for the Future (GHRF Commission) states in their 2016 report titled The Neglected Dimension of Global Security: A Framework to Counter Infectious Disease Crises that "we have not done nearly enough to prevent or prepare for such potential pandemics. While there are certainly gaps in our scientific defences, the bigger problem is that leaders at all levels have not been giving these threats anything close to the priority they demand" (National Academy of Medicine, 2016). We will reference this report in more detail later in this paper, as it is encyclopaedic yet admonishing and instructive for pandemic planners. The GHRF consider pandemic planning a neglected dimension of security, which places the onus of responsibility on the shoulders of all governments. Supporting the GHRF, the 2019 Global Health Security Index Report (the first of its kind) notes that "Countries are not prepared for a globally catastrophic biological event, including those that could be caused by the international spread of a new or emerging pathogen or by the deliberate or accidental release of a dangerous or engineered agent or organism" (Global Health Security Index, 2019, p. 9).

At the time of publication, the justification for our research can be seen in the infection, death, and recovery statistics between the four countries under discussion, as seen in Figure 2. The USA has the highest infection rate in the world, with the figures placing the UK fourth behind Brazil and Russia. The USA also has the highest number of deaths, followed by the UK, which, when compared to Germany and South Korea, makes for dire reading. 
COVID-19 Dashboard by the Center for Systems Science and

Engineering (CSSE) at Johns Hopkins University (JHU)

\begin{tabular}{|c|c|c|c|}
\hline COUNTRY & INFECTIONS & DEATHS & RECOVERIES \\
\hline USA & $6,466,012$ & 193,351 & $2,417,878$ \\
\hline UK & 367,590 & 41,712 & 1,873 \\
\hline GERMANY & 260,817 & 9,352 & 231,953 \\
\hline SOUTH KOREA & 22,055 & 355 & 18,029 \\
\hline & $\begin{array}{r}\text { last Updated at } \\
\mathbf{1 2 / 2 0 2 0} 19: 26\end{array}$ & \\
\hline
\end{tabular}

Figure 2 COVID-19 infections, deaths and recoveries as of 12 September 2020.

Source: https://www.arcgis.com/apps/opsdashboard/index.html\#/bda759474ofd40299423467b48egecf6.

Our research will evidence that pandemic planning is a normative practice within almost all countries. Therefore, we reject the argument that COVID-19 is a "Black Swan" event. Such an event would require for there to be a severe limitation of learning and for there to be fragility in the knowledge. Yet in respect of pandemic preparedness, our research has found the governments across the globe did not lack any limitations or knowledge in respect of preparation for an influenza pandemic and the modelled impact it would be likely to have on their countries. Our research found the opposite was the case, and this paper has government papers as the primary basis of our argument. Murphy, Jones, and Conner help strengthen our argument by noting that "multiple warnings from experts in epidemiology and related public health fields that a major pandemic is not a question of if, but only of when-the current pandemic cannot be viewed as a Black Swan" (Murphy, Jones, and Conner, 2020). They continue their argument by stating that COVID-19 does not meet Taleb's first criteria in that it lies outside the realm of regular expectations but caveat that by stating "the pandemic is still evolving and could take a surprise turn before it is finished. But if nothing appears which would satisfy Taleb's first criteria, then our conclusion would remain unchanged" (Murphy, Jones, and Conner, 2020). The plethora of research, reports, government publications, risk assessments, and historical comparisons of flu pandemics would disprove without any difficulty the notion of a "Black Swan" event.

The obvious question, therefore, is that if it is not a "Black Swan", why have the responses to COVID-19 been so noticeably different despite the apparent high-levels of planning and preparedness between the UK, the USA, Germany, and South Korea?

\section{Organization of the paper}

Having framed the context of this paper and provided preliminary evidence of the levels of preparedness for the current COVID-19 pandemic, we present our paper through three sections. Section three will outline the history of pandemics and place them into the context of COVID19. In this section, we outline historical pandemics and epidemics from both the 2oth century and some specific named events from earlier centuries that had a global impact. Section four moves to a discussion on the preparedness (or lack thereof) and response of each of the four countries. From this discussion, we conclude the contrasting economies of the UK and the USA, and those of Germany and South Korea, reflects the response and preparedness to COVID19. Section five then presents two differing economic ideologies, that of state intervention, as 
Vol. 7, No. 1, 9-45.

postulated by John Maynard Keynes and what we call 'Keynesian economics' (Jones, 2014), and the opposing ideology of neoliberal free-market economics. Neoliberalism will be discussed through the arguments of Friedrich Hayek (Hayek 1960; Fukuyama, 2011) and Milton Friedman (1962), what we call "Chicago school economics". This discussion will address the systematic and inherent weaknesses of neoliberalism through a comparison of the economic principles that underpin Germany and South Korea. The purpose of this comparison is that Germany and South Korea have what are known as mixed economies, where there is significantly more government management intervention and control over the markets, and less privatization and de-regulation. Our research and primary argument are that the lack of preparedness by the UK and USA compared to Germany and South Korea is due to the ideology that underpins the economics of each country. This analysis is essential as it underpins our argument that the level of investment and ongoing planning in healthcare has determined the responsiveness and preparedness of the countries under discussion.

The basis for our research has been outlined in the introduction, however, the contrast of the UK and USA with Germany and South Korea is important for three reasons. Firstly, the UK and USA have entirely different policies that underpin their economies compared to Germany and South Korea. Secondly, the UK, Germany and South Korea are similar in terms of their population. Thirdly, the UK and USA were manufacturing giants, the UK in particular with its origins in the Industrial Revolution (Hobsbawm, 1968; Allen, 2011). We will evidence that the 1970 started a decline in manufacturing output from the UK and USA, which is in marked contrast to Germany and South Korea.

Both Germany and South Korea have become undisputed manufacturing powerhouses, and yet both have similar histories in that they were faced with rebuilding their economies after years of devastating world wars (Allen, 2005; Eich-Born and Hassink, 2004). Germany after World War Two (WW2) and South Korea after the Korean war of 1950-1953; a war that stood as the most dangerous armed conflict globally and politically since the surrender of Germany and Japan in 1945 (Stueck, 2007). Germany could arguably be described as defunct militarily, politically, and economically by the end of WW2, with South Korea engaging in a war with no victor and a weak agrarian economy (Kim, 1991). Since the 1950s, both Germany and South Korea have established their economies on manufacturing output, whilst simultaneously the UK and USA decimated their manufacturing production through adopting fundamentally different economic doctrines.

We will argue and evidence that this decline is a direct result of the adoption of neoliberal, free-market economics through the 1980 s and 1990 os by the UK and USA. Succinctly put, throughout the 21st century, Germany and South Korea have continued to manufacture for both their home and export markets. The UK and USA, however, have reduced their domestic manufacturing capabilities and instead have outsourced manufacturing (primarily to the far East), resulting in both their import and export markets largely comprising of externally produced goods. The decline from the West, in general, of manufacturing has coincided with a global shift back to the East from the West. This global shift will be evidenced as part of our discussion. Dintenfass (1992) offers a sad indictment of Britain's industrial decline by noting that between 1960 and 1974 Britain's share of world trade in manufactured goods declined from 15 to 8 per cent (Dintenfass, 1992, p. 58). It is an almost identical story with the USA in respect of employment in the manufacturing marketplace. The US share of world exports fell from 17 per cent in 1963 to less than ten per cent by 2007, and its imports surged from less than nine per cent to 13 per cent in the same period (Dicken, 2011, p. 27). Dicken notes that in respect of outward Foreign Direct Investment (FDI) between 1990 and 2007, more than 80 per cent originated from 15 countries. It came as no surprise in our research that the leading two source countries are the UK and USA, which account for almost 30 per cent of the world total. It is also no surprise that over half of the inward FDI investment in developing countries is concentrated in just five host countries, with almost 30 per cent concentrated in China and Hong Kong alone (Dicken, 2011, p. 25). 
While the USA has maintained a manufacturing base within its borders for decades, there has been a permanent decline since the 1970s in manufacturing. There is a large number of studies on this subject, which we refer to in section four, but suffice to say that the subject of globalization has a direct correlation to the level of real preparedness, rather than the perceived level by the UK and the USA, which is in stark contrast to Germany and South Korea.

We argue that aside from any notable cultural differences between the UK, the USA, Germany, and South Korea (Hofstede, 1980, Horak, 2005), the economic model differences between the four countries either aided or hindered the responses to the COVID-19 pandemic. The contrasts between the four countries will be examined through their responses to the pandemic whilst accounting for their population sizes. The UK and Germany account for similar population density per square mile and overall population sizes. The UK population is 67.8 million, and Germany population is 83.8 million. The American population is 36 people per square kilometre, with a total population of 331 million, whilst the South Korean population has the highest density per square mile at 527 people and a total population of 51.2 million (Worldometer, 2020).

Our conclusion is almost an epitaph to neoliberalism and its systemic weakness, which we argue and will evidence left the UK and USA unprepared for a pandemic. Our argument for the lack of preparedness of the UK and USA has its roots in the adoption of "small government", and since 2008 is directly linked to the austerity measures implemented by the Conservative-Liberal Democrat coalition UK government of David Cameron and his Chancellor of the Exchequer, George Osborne (Fairclough, 2015, Stuckler et al., 2017). We will conclude that contemporary capitalism has imploded, that the principle of endless accumulation that defines this form of capitalism leads to destruction, devastation, and serfdom (Amin, 2010; Amin, 2013). Alternative economic policies are required for the UK and USA, and we offer some consideration for this based on research by others far more esteemed than ourselves.

\section{Synopsis of historical pandemics}

\section{Introduction}

The SARS-CoV-2 outbreak, known as the COVID-19 outbreak, has shaken the world as we know it. The virus outbreak originated in Wuhan, China, at the end of 2019, with the origins of the outbreak still being discussed (Hoehl et al., 2020; Shereen et al., 2020). Some expert virologists have suggested that the pathogen may have originated in the "wet markets" of Wuhan (Chen et al., 2020). The experts have suggested that the SARS viruses are zoonotic viruses, meaning they originate in animals and jump from animals to humans. A similar argument has been presented as to the origins of the "Spanish Flu" influenza outbreak where it was suggested human influenza and a certain bird virus was hosted in pigs and the virus mutated into the $\mathrm{H}_{1} \mathrm{~N}_{1}$ virus (Vincent et al., 2009; Klein et al., 2020).

It is possible a host of different viruses may have mutated in the Wuhan wet markets; however, as Chinese official Zhao Lijian has argued, this virus may have originated from a lab. Other Chinese officials have argued that the United States has used the outbreak to weaponise blame against the Chinese to further aggravate relations between the two nations (Panda, 2020). Additionally, an Israeli "biological warfare analyst" Dany Shoham argued this virus was mutated in China's Wuhan Institute of Virology and claimed the Chinese have a "covert bio-weapons program" that leaked or weaponised the virus (Perry, 2020). Furthermore, there has been reports of this virus appearing in France in December 2019, and northern Italy around that time before the Chinese outbreak. The sources remain subjects of debate and remain unverified (Irish, 2020; Parodi and Aloisi, 2020). 
Vol. 7, No. 1, 9-45.

Regardless of its source, this virus has spread across the globe, putting approximately three billion people in lockdown as a result (Petherick, 2020), affecting the global economy, and causing medical facilities to be stretched, as seen in Italy, Spain, the United States, the United Kingdom, France, and various other countries. Governments around the world have known about the threat of major viral outbreaks with many of them having extensive pandemic planning in place, however, despite this many of them were not adequately prepared for the outbreak of COVID-19 (Otte, 2020; Gudi and Tiwari, 2020; Tyler and Gluckman, 2020). The primary question of this paper is to explore why the Western countries were not as prepared for this outbreak. There are various arguments for this ill-preparedness, in general and specifically in the UK and USA, in relation to this paper. One of the primary arguments made by Noam Chomsky is that the neoliberal economic model implemented in the post-Cold War world is the likely main reason for the ill-preparedness of western states (Chomsky, 2020). The following segments will explore the history of pandemics and how the COVID-19 pandemic can be compared and cross-examined against them. Lastly, we will discuss the impact that neoliberalism may have had in the mishandling of the current COVID-19 pandemic.

\section{Ancient pandemics}

This following segment will primarily discuss the history of pandemics in comparison with the COVID-19 outbreak. Since the dawn of civilization, reportedly in Mesopotamia, humans have domesticated animals and have been in contact with livestock. This resulted in countless outbreaks of diseases and epidemics. Such diseases were spread through trade routes and wars alike, with some having minute influence concerning their potential threat posed to human life while others posed a significant threat, resulting in their classification as epidemics (Algaze, 2018). Some ancient religious and sacred texts from ancient Egypt, Greece, and Mesopotamia record some viral outbreaks of their times (Shchelkunov, 2009), with one of the first recorded epidemics, the "Plague of Athens" recorded by the Greeks from 426-429 BCE. The disease is still unidentified but a study in 2006 suggested it was a typhoid fever outbreak and gave us a glimpse into the nature of the epidemic (Papagrigorakis et al., 2006). Due to poor hygiene and sanitation in Athens during that time the plague resulted in the deaths of $20-30 \%$ of the contemporary population, as it spread from Ethiopia, Egypt, Libya, and the rest of eastern Mediterranean regions, and thus could be categorised as a pandemic (Poole and Holladay, 1979; Littman, 2009).

The next recorded pandemic occurred during the Roman Empire 165-190 BCE, known as the "Antonine Plague". Archaeological evidence and documentation suggest that it was possibly smallpox or a measles outbreak. The pandemic is believed to have originated in Mesopotamia and then been brought to the Roman Empire by the military (Bruun, 2007), and proved to be highly contagious. It is believed to have resulted in the death of approximately five million people, around 20 per cent of the Roman Empire's total population at the time. This had severe repercussions on the empire with a significant reduction in their army, and caused the death of the Roman emperors of the time, Lucius Verus and Marcus Aurelius. The Italian paper by Sabbatani and Fiorino (2009) claims the fall of the western Roman Empire was a result of the "Antonine Plague" and weakened its state structures. This gives light to the severity of public health and the risks of continuous pandemic outbreaks, and it highlights the need for adequate preparation for such outbreaks through rigorous planning and continuous stabilised investment in healthcare systems as we consider the 21st-century impact of pandemics on society.

Many other epidemics occurred over time, the "Justinian Plague" in the Byzantine Empire in 541 CE became known as the first Bubonic Plague. This was one of the first longlasting epidemics, lasting several decades and resulting in an estimated death of between 
25-100 million people in West Asia and Europe. As such, the Justinian Plague is largely credited for the reduction of the Byzantine Empire during the period (Alchon, 2003, p. 28-31). Among the significant ancient pandemics, the "Black Death", which occurred in $1346 \mathrm{CE}$, was the most severe, resulting in the death of 75-200 million people. This Bubonic Plague was the most devastating outbreak in recorded history, with approximately 50 per cent of the European population fatally contracting the disease (Alchon, 2003, p. 21-28; Abdelbaqi, 2014).

The living standards, scientific medical knowledge and preparedness of the states and civilizations were not as we have in the modern era. The lack of sanitation, hygiene, the supply of freshwater, medicine, and the contemporary urban living conditions of those times made it easier for such outbreaks of disease to spread (Alchon, 2003, p. 53). The concept of "Quarantine" comes from the famous Arab scientist Avicenna (Ibn Sinha) in his book The Canon of Medicine, and he explained the importance of the isolation of patients for 40 days to reduce the outburst of these viruses that are transmitted through human contacts; a suggestion made in 1025 (De Haan, 2018; Islam et al., 2009). It is remarkable that for all the development of medicine and science, isolation is still the primary part of any strategy for curbing epidemic outbreaks in the modern age. The quarantine was later utilised during the "Black Death" in an effort to try and curb its spread.

If the responses of the ancient civilizations are analysed, it is evident that the more successful cases happened due to proactive steps from the authorities or government, a point of historical learning that appears to be missed in this current COVID-19 outbreak. For instance, during the "Black Death", the city of Milan incorporated draconian measures by blocking off windows and doors of the infected civilians, resulting in a very low death percentage in the city (Bray, 2004, p. 70). This is in contrast to other Italian city-states; the responses elsewhere were more passive and resulted in high death rates. Although there are fundamental differences in bubonic outbreaks and influenza, the methods of response remain the same. During the "Black Death", the European city-states adopted quarantine measures on ships docking in their ports, where they were often told to wait for 40 days for assurance. Therefore, it is evident that the more proactive measures taken by authorities generally result in lower death rates in comparison to more passive, laissez-faire approaches (Bray, 2004, p. 5-12).

\section{Modern pandemics}

The severity of ancient outbreaks was documented in the Greek and Roman times with the consequences of these epidemics being analysed in the modern era. The deadliest outbreak of the "Black Death" has taught various important lessons and, with the help of modern medicine, various diseases have been defeated. With the invention of vaccines, diseases such as Smallpox have been eradicated globally whilst others such as Polio have seen their spread efficiently mitigated through rigorous international vaccination programmes (Henderson, 2011; Tárnok, 2020; Moormann, 2020). The most significant casualties were caused by outbreaks such as the Bubonic Plague, Yellow Fever, Smallpox, and Measles. From recorded history it can be seen that influenza outbreaks did not cause high casualties. However, in 1918 the influenza virus $\mathrm{H}_{1} \mathrm{~N}_{1}$, famously known as the "Spanish Flu", was the first large-scale influenza outbreak, which resulted in 17-100 million deaths worldwide. In comparison, as a percentage of the population, this was far lower than the ancient plague outbreaks due to the increase in total population numbers. Interestingly, this was the first recorded mutation of the influenza virus that resulted in the loss of millions of lives (Hays, 2005).

Influenza has four primary strains of viruses $(A, B, C, D)$, but they can mutate and generate new models of the virus, almost at will, therefore, influenza vaccines are largely ineffective in the world today (Lim et al., 2005). Influenza A H1N1 first broke out during the 
Vol. 7, No. 1, 9-45.

Russian flu 1889, then Spanish flu 1918. Following that were the $\mathrm{H}_{2} \mathrm{~N}_{2}$ outbreaks during the Asian flu 1957 and the $\mathrm{H}_{3} \mathrm{~N}_{2}$ Hong Kong flu 1968 (Potter, 2001). There have been various other influenza outbreaks in recent times; the most recent was the 2009 outbreak of the $\mathrm{H}_{1} \mathrm{~N}_{1}$ outbreak, more commonly known as the swine flu (Lim et al., 2015). According to the official statistics of the Center for Disease Control and Prevention (CDC), this was first detected in the USA and spread quickly across the world. As with previous mutations, the new $\mathrm{H}_{1} \mathrm{~N}_{1}$ virus contained a unique combination of influenza genes not previously identified in animals or people. CDC official data is that:

between April 12, 2009 to April 10, 2010, there "were 6o.8 million cases (range: 43.389.3 million), 274,304 hospitalizations (range: 195,086-402,719), and 12,469 deaths (range: 8868-18,306). Additionally, CDC estimated that $151,700-575,400$ people worldwide died from $\left(\mathrm{H}_{1} \mathrm{~N}_{1}\right)$ pdmog virus infection during the first year the virus circulated.

(2009 $\mathrm{H}_{1} \mathrm{~N}_{1}$ Pandemic, 2020) With the world population increasing and with more travel and global trade, the outbreaks in the 2oth century have become more manageable. Cross continental travel, European empires, and global trade have enabled viruses and diseases to spread faster than they have ever done (Hays, 2005). Furthermore, it must also be considered that in the 2oth century the majority of the world population had descended from the survivors of the previous plagues and had developed immunity and resistance to a lot of the ancient plagues (Hays, 2005). Despite this, the dangers of mutating viruses remain the biggest threat to the contemporary human population, therefore, the governments of various states have invested in finding vaccines to immunise its populations from emerging disease outbreaks (Moormann, 2020). In the post-WW2 world, the global economy suffered deeply due to wide-scale political and economic ideological wars.

The neoliberal ideology emerged from the Cold War period with the help of the Chicago School of Economics and their influence from Fredrick Hayek. The neoliberal economic ideology was later exported to South America, Russia, the UK, and various other developing countries (Klein, 2008). The results of privatization and deregulation as preached by this ideology has reduced public spending and the overall drop in quality of services in these countries. This topic will be covered in detail in section four of this paper, as we turn to the current pandemic to discuss the preparedness and responses of the UK, the USA, Germany, and South Korea. In the next section, we will evidence an imbalance in healthcare investment and how cuts to public services has debilitated the responses of the UK and USA to COVID-19 in noticeable contrast to Germany and South Korea, where there have been high-levels of government management and investment in healthcare.

\section{Preparedness and responses}

\section{Introduction}

We noted in the introduction that the timing of COVID-19 in and of itself could not have been planned for by any government. However, we will argue and evidence in this section that the level of preparedness is unrelated to the timing of the pandemic itself. Our primary argument is that, despite all the reports that would suggest that the UK and USA were prepared for a pandemic, the reality when COVID-19 emerged and spread was to the contrary. In respect of the UK to such an extent that one health worker in the UK stated: "When this is all over, the NHS England board should resign in their entirety" (Horton, 2020). Our secondary argument, which develops in this section and concludes in section five of this paper, is the root cause of the lack of preparedness by the UK and USA governments. This root cause, we argue, is that the continued adoption of neoliberal economic policies 
brought about the financial crash of 2008. This ushered in austerity measures in the UK, which led to massive cuts in public spending, and specifically cuts to the UK National Health Service, including elements of privatization (Appleby, 2015; Naylor, 2017). This, in turn, has resulted in the UK health service and government departments being anything but prepared for COVID-19. This "domino effect", a "sequence of rotations interrupted by collisions" (Van Leeuwen, 2010), is the basis of our argument and we use international and national government reports to support this argument in the sub-sections that discuss each of the four countries under the microscope.

The basis for this argument in respect of the UK is a series of government and public health sector reports together with simulations that demonstrate, since 2008 and up to 2017 , the UK knew the potential impact a pandemic would have on their health service and economy. The USA engaged in their simulation and their 2019 report will be used to evidence this together with additional US government reports. The official reports from the UK and USA support the narrative of a highly respected international report of October 2019, titled the Global Health Security Index, which uses an assessment of 80 factors across six categories to identify the level of preparedness of 195 countries. The six categories are: 1) Prevention; 2) Detection and Reporting; 3) Rapid Response; 4) Health System; 5) Compliance with International norms; and 6) Risk Environment (Global Health Security Index, 2019, p. 9). The GHS Index is a project of the Nuclear Threat Initiative, by the Johns Hopkins Center for Health Security, and was developed with The Economist Intelligence Unit (Global Health Security Index, 2019, p. 5).

In contrast to the UK and USA, we will discuss how Germany and South Korea were not only prepared, but the official statistics and international commendation for the "textbook" responses show that their plans and planning reflected their ability to respond swiftly and in accordance with their published plans. We will use multiple sources to evidence that both Germany and South Korea were not only highly prepared but have a governmental structure and economic policies that enabled both countries to respond to the pandemic at speed. Germany has been the subject of an international commendation, by governments and the World Health Organization for their response (Jowett, 2020; Buranyi, 2020). In respect of South Korea, the official statistics tell their own story of not only the level of preparedness of South Korea but also their "textbook" response to the pandemic (Maizland and Felter, 2020).

In defence of all countries, the GHS Index report states that:

"Overall, the GHS Index finds severe weaknesses in country abilities to prevent, detect, and respond to health emergencies; severe gaps in health systems; vulnerabilities to political, socioeconomic, and environmental risks that can confound outbreak preparedness and response; and a lack of adherence to international norms."

(Global Health Security Index, 2019, p. 9) Adding to this, they point out that "no country is fully prepared for epidemics or pandemics. Collectively, international preparedness is weak" and "many countries do not show evidence of the health security capacities and capabilities that are needed to prevent, detect, and respond to significant infectious disease outbreaks"

(Global Health Security Index, 2019, p. 39). If the GHS Index report were the primary basis of this paper alone, and this paper was predicting preparedness, then our argument could only be that the UK and USA are the bestprepared countries to deal with a pandemic. The report has the UK and USA as being the most prepared countries with scores out of 100 of 77.9 and 83.5 respectively across five of the six main categories, with Lichtenstein taking the other place (Global Health Security Index, 2019, p. 21). South Korea is higher than Germany at 70.2 with Germany scoring 66.o out of 100. Out of four of the six categories, the USA ranked first, with the UK ranking first in the category of Rapid Response to and Mitigation of the Spread of an Epidemic (Global Health 
Vol. 7, No. 1, 9-45.

Security Index, 2019, pp. 7-8). The results of the GHS Index would, on the surface, mean the UK and USA should have been able to fight COVID-19 in a more robust way than they have. Despite these rankings, the reality of the level of preparedness by each country under discussion has been remarkably different. It does appear that the GHS Index report grossly overestimated the resourcing, capacity, and preparation of the healthcare systems of both the UK and USA. We expand on this perspective through the following sub-sections where we individually evidence each country's preparedness and response to COVID-19.

\section{UK preparedness and response}

How did a country that supposedly had a set of the most comprehensive pandemic plans in the world end up suffering one of the worst outbreaks, and having the second-highest death toll in the world at the point of publication?

The UK has its iconic and deeply valued National Health Service (NHS) system, however, after the global recession in 2008, the Conservative government at the time introduced austerity measures, which greatly impacted the services' funding at regional and community levels. The cost-cutting measures introduced resulted in depleted services, hospital closures, and mass shortages of healthcare staff, which arguably hindered NHS capacity to cope with the COVID-19 outbreak. The current Conservatives, somewhat adherents of Margaret Thatcher and neoliberalism, have emphasised the continued reduction of state-funded services. There has been a continuous cycle of cuts to the NHS under both Conservative and Labour governments since 1984 under Thatcher, John Major in the 1990s, the Blair administration in the 200os, and then under the coalition government headed by David Cameron (Bale, 2017, Hall, Lister, and Mercer, 2020). The Hall, Lister, and Mercer Report, alongside Appleby's paper on the cuts within the NHS, all strongly argue that both the impact and consequences of four decades of cuts, privatization, and deregulation of the health service has been catastrophic in the context of COVID-19. Between 2010 and 2015, the consensus on the value of the gap between cuts in services and required expenditure to NHS England is £2obn and scaled for the rest of the UK is £24bn (Appleby, 2020).

We referenced in the introduction that there were a plethora of UK government reports and plans in respect of pandemics. It would be a paper in itself to discuss each of them, but suffice to say that it is a damming incitement on the Conservative-led governments of the last ten years that the UK lacked the preparation when COVID-19 hit. In our research we found none less than ten official documents that are unambiguous in their message; a pandemic represents a major threat to the British healthcare system and economy to which there were multiple plans to manage such a pandemic. Having already referenced the 2008 National Risk Assessment, we now cite four other key reports. These extracts are in context and evidence that cabinet ministers knew (or ought to have known) what response was needed in the event of a pandemic. What is deeply concerning is that the reports and risk assessments are encyclopaedic and would leave any reader with the belief that the UK was prepared and that the rankings given by the GSH Index are correct.

Firstly, the UK Influenza Pandemic Preparedness Strategy 2011, which notes in section 1.7 of its introduction that "The UK has been preparing for an influenza pandemic for some years. These preparations were tested by the $\mathrm{H}_{1} \mathrm{~N}_{1}$ (2009) influenza pandemic" (DHSSP, 2011, p. 7). In section 2.18, titled "Lessons from the $\mathrm{H}_{1} \mathrm{~N}_{1}$ (2009) influenza pandemic" they note that "there are no grounds for complacency and any presumption that the relatively mild $\mathrm{H}_{1} \mathrm{~N}_{1}$ (2009) influenza pandemic is representative of future pandemics is dangerous" (DHSSP, 2011, p. 13). Section 2.19 outlines that influenza pandemic planning in the UK has been based on a reasonable worst-case scenario that is derived from previous pandemics, the type of which we have discussed in section three, and seasonal influenza as a common occurrence in the 2oth century. 
This risk assessment presented the suggestions that given known patterns, up to 50 per cent of the population could experience symptoms over a pandemic wave lasting 15 weeks. On the subject of the expected death toll, the report notes that local planners should prepare to extend capacity and aim to cope with a mortality rate of 210,000-315,000 deaths, possibly over as little as 15 weeks (DHSSP, 2011, pp. 14-17). The number of predicted deaths is down from 500,000 - 750,000 that were in the 2008 Risk Assessment that formed part of the introduction at the beginning of this paper (UK Cabinet Office, 2008). The remainder of the report outlines the new strategy on how to respond to the pandemic, which takes the form of a series of stages named, Detection, Assessment, Treatment, Escalation, and Recovery. These phases are not numbered as they are not linear, and therefore there will be a requirement, where needed, to move back and forth or jump phases (DHSSP, 2011, p. 27).

We have chosen to detail this risk assessment and strategy as this 2011 preparedness strategy report, nine years old at the point of COVID-19, remarkably is the same strategy that was used during Exercise Cygnus in 2017, which was a three-day simulation of the impact of a pandemic within the NHS (Pegg, 2020). This report has been a contentious issue politically as the current UK government under Prime Minister Boris Johnson is refusing to publish the report (Pegg, 2020). The purpose of the 2017 report was "to update the Board on NHS Emergency Preparedness, Resilience and Response (EPRR) in line with the statutory requirements placed upon NHS England by the Civil Contingencies Act (2004) and the NHS Act (2006) as amended by the Health and Social Care Act (2012)" (NHS England, 2017). The point of this citation is that the issue of dealing with a pandemic is underpinned by English Law - the Civil Contingencies Act, 2004.

Section 2(1)(c) of this law states that a person or bodies listed shall maintain plans to ensure that if an emergency occurs or is likely to occur the person or body can perform his or its functions. So far as necessary or desirable for the purpose of, (i) preventing the emergency, (ii) reducing, controlling, or mitigating its effects, or (iii) taking other action in connection with it.

(Civil Contingencies Act 2004) Preparing for a pandemic and taking all necessary steps to prevent, reduce, or control it is a matter of UK law; not something to be taken lightly. It is yet to be seen if this law will be used by individuals in future litigation. If the topic of a pandemic is also a legal matter, why then was the issue of preparedness not constantly updated and planned for? Besides, it could be argued that under the Civil Contingencies Act 2004, the UK Government has a legal obligation to publish any reports.

The UK believed it was prepared as other reports articulate. At the onset of a pandemic influenza epidemic in the UK there "will not be a good vaccine that matches the characteristics of the new virus" (Scientific Pandemic Influenza Group on Modelling, 2018, p. 16). This would not prohibit the UK government from working with pharmaceutical and bio-science companies to ensure preparedness, however, under a neoliberal economy, this would not be easy to achieve. We argue this as neoliberalism "focuses on profit rather than human rights indicators, which disempower people, whose health needs are subordinated to the needs of the market. Neoliberalism treats healthcare as private good for sale rather than a public good paid for with our taxes" (Fouskas and Gökay, 2020). When a country is market-driven then short-term profit and increasing share prices become the Key Performance Indicators (KPI) that drive behavior. It is inconceivable that a company could manufacture or stock items such as Personal Protection Equipment (PPE) in the belief that the government would purchase them. It could be argued that it is the responsibility, under the Civil Contingencies Act 2004 to "warehouse" and keep in-date PPE to match the levels of infection and mortality rates that the plans project. 
Vol. 7, No. 1, 9-45.

The 2012 Health and Social Care Influenza Pandemic Preparedness and Response report would leave any Prime Minister and its Cabinet under the assurance that the UK was prepared. They note that:

an influenza pandemic could emerge at any time of the year anywhere in the world, including in the UK. Regardless of where or when it emerges, it is likely to reach the UK very rapidly and, from arrival, it will probably be a further one to two weeks until sporadic cases and small clusters of cases are occurring across the country.

(Department of Health, 2012, p. 10) This report expands on recommendations and planning requirements in respect of leadership, ethical principles, clinical and user engagement, communication, infection control, resilience and business continuity, human resources, and finally training (Department of Health, 2012, pp. 17-23). It would be remiss of us not to mention the grandly titled advisory group The New and Emerging Respiratory Virus Threats Advisory Group (NERVTAG), which opens with a foreword from the Chairperson who states that:

NERVTAG provides independent scientific risk assessments and advice to the Department of Health (DH) over a wide range of subjects relevant to the threats posed by new and emerging respiratory viruses. Pandemic influenza is, of course, the predominant threat and, combining likelihood and impact, remains the foremost civil risk to the UK as identified in the UK National Risk Register.

(NERVTAG, 2019)

This report at the outset confirms what was already known - that the biggest risk to the UK is an influenza pandemic - and yet, regardless of the scientific advice, there was an unquestionable lack of preparedness. We could cite so many other reports, planning documents, risk assessments, and frameworks from different departments, governing bodies, and the emergency services.

Despite over 10 years of influenza pandemic planning, when COVID-19 hit the UK in January 2020, the evidence proves that neither the Government, Public Health England, nor the private sector was ready or prepared to deal with COVID-19. The report author of the Exercise Cygnus, Helen Shirley-Quirk (the then director for emergency preparedness and health protection policy at the Department of Health) stated that "The UK's preparedness and response are not currently sufficient to cope with the extreme demands of a severe pandemic" (Sabbagh, 2020).

The UK's first National Director of pandemic influenza preparedness, Prof Lindsey Davies, in 2007 ran a more detailed simulation than Exercise Cygnus, called Winter Willow, in which "over 5,00o people from a large number of UK organizations representing government, industry and the voluntary sector participated in Exercise Winter Willow, with a common aim to check our preparation for the major disruptive challenges that an influenza pandemic may bring" (Department of Health, Cabinet Office, Health Protection Agency, 2007). Winter Willow was far larger than Exercise Cygnus, which involved 950 people. Winter Willow marshalled more than 5,00o people, including government ministers, civil servants, emergency planners, NHS staff, and emergency services personnel to coordinate the first real attempt to test how the UK would hold up under the strain of a pandemic (Pegg, 2020). According to Prof Davies, "We did not exaggerate it at all if anything we underplayed it. We had a sort of moderate pandemic scenario, rather than the worst-case one. But even then", she added, "We ran out of face masks" (Pegg, 2020).

The topic of face masks is part of the PPE narrative that has been a dominant theme in the media and the Government daily briefings. In 2007, it was known that there was a risk of running out of face masks, the most basic of PPE equipment needed to protect health workers from infection. Writing in The Lancet, Horton is excoriating on his attack on the NHS supply chain by stating that: 
Even where there is PPE, there may be no training. WHO standards are not being met. Proper testing of masks is being omitted. Stickers with new expiry dates are being put on PPE that expired in 2016. Doctors have been forced to go to hardware stores to buy their face masks. Patients with suspected COVID-19 are mixing with non-COVID-19 patients.

(Horton, 2020)

Despite warnings since 2007, when COVID-19 emerged the UK (and the USA) were faced with an enormous lack of PPE, and to look at the causes of this we must look at the NHS Supply Chain. In a comprehensive 2020 report, titled Privatised and Unprepared: The NHS Supply Chain, the report author's first sentence states "Months after the arrival of the Covid-19 pandemic, huge numbers of UK health and care workers still lack adequate personal protective equipment" (Hall, Lister, and Mercer, 2020, p. 3). The authors are unflinching in the aims of their report when they write:

This report aims to expose the role that the privatisation of health and social care has played in this preventable catastrophe. Privatisation has created a system which is both chaotic and bureaucratic - both fragmented and sclerotic. There has been an outcry over PPE shortages in media coverage of the pandemic, but little has been said about privatisation. This is a serious oversight, which this report will address.

(Hall, Lister, and Mercer, 2020, p. 3) The NHS Supply Chain is technically part of the NHS and is headed by the Secretary of State for Health. In reality "this status is merely a fig-leaf for a needlessly complex web of contracts with private companies who answer to shareholders first" (Hall, Lister, and Mercer, 2020, p. 3). The report describes the NHS Supply Chain as heavily privatised, convoluted, and fundamentally dysfunctional. It has created layers of corporate red tape between doctors and nurses who need PPE to work safely and the private companies supplying the said PPE.

The UK was not prepared for COVID-19 and yet, as we have argued beyond any doubt (rather than reasonable doubt), the UK could have been prepared, should have been prepared, and yet instead of accountable and co-ordinated leadership, there is fawdia, (Oxford Arabic Dictionary: Arabic-English/English-Arabic, 2015), chaos, and disarray. Horton continues his polemic in The Lancet and suggests that chaos has been the norm, stating:

[the] UK Government's Contain-Delay-Mitigate-Research strategy failed. It failed, in part, because ministers didn't follow WHO's advice to "test, test, test" every suspected case. They didn't isolate and quarantine. They didn't contact trace. These basic principles of public health and infectious disease control were ignored, for reasons that remain opaque.

(Horton, 2020)

Horton's polemic against government planning stating that preparedness plans and required staff and equipment (such as PPE, hospital supplies, ventilators, and the healthcare workers) should have been readied for deployment at short notice.

Our argument at the outset of this paper and this section is that the neoliberal phase of capitalism, deregulation, outsourcing, and privatization has hindered not helped the NHS and the government to respond to COVID-19. Professor David Tuckett has some sympathy noting that it would be natural for ministers and health leaders to turn to their flu pandemic plans; after all, it was all that they had. However, the peril of placing assumptions in the core of government planning is the assumption that the crisis being dealt with is what was planned for.

Future studies will no doubt offer detail in respect of the UK response, however, the current journal articles and commentary from the British Medical Association and The Lancet, in addition to media commentary, all show the delayed response from the UK Government 
Vol. 7, No. 1, 9-45.

was insufficient to meet the pandemic. It could be argued that the delay strategy of the UK government was deliberate because the leadership knew that the all-important PPE was lacking. Not only was it lacking in quantity but much was also out of date and in some cases even had altered expiry dates, which raised alarm bells within the nursing profession (Gilroy, 2020). Our research on the topic of PPE and expiry dates confirmed that the average lifecycle of PPE is between three and five years from the date of manufacture according to the market leader, $3 \mathrm{M}$ (3M plc, United Kingdom, 2020).

We can summarise the UK response by the acknowledgement of the UK Prime Minister, Boris Johnson, when he stated that "We didn't learn the lesson on SARS and MERS" (COVID-19 News, 2020). Is this not an incriminating inditement considering the level of alleged preparedness that is in the government domain? This, despite the position of The Independent Scientific Advisory Group for Emergencies (SAGE) stating in their report of the 12 May 2020 that "It has taken many years of detailed biological, clinical, and epidemiological studies to generate a strong evidence base of understanding prevention, treatment and immunity for other infections" (The Independent Scientific Advisory Group for Emergencies (SAGE) 2020, p. 8). Having discussed at length the UK, we now turn to the preparedness of the USA, Germany, and South Korea, which will be more succinct.

\section{USA preparedness and response}

As noted in the previous section, the response of the USA was disjointed (Maizland and Felter, 2020). The USA, the self-proclaimed guardians of free-market capitalism, implemented neoliberalism during the Ronald Regan administration in the 1980s and have continued with it as their primary economic model up until the present day. Post-WW2, under President Franklin D. Roosevelt, the USA started to adopt free-market capitalism to counter the spread of Sovietsponsored communism and its social or government-funded programs (Smith, 2020). The impact of this is a privatised healthcare service for its citizens and little support for vulnerable and low-income citizens. This has resulted in 8.5 per cent of its population going without any form of healthcare coverage and makes the USA one of the only high-income countries that has not achieved universal healthcare coverage (Maizland and Felter, 2020).

To place that into perspective, Bismark sought to gain blanket healthcare in Germany in 1883 , the UK implemented national coverage in 1948, and South Korea achieved this by 1989 (World Health Organization, 2014; 2015). It can be argued, as a result, that the current pandemic has hit the USA harder than any other country globally, with over 1,793,530 infections and 102,836 deaths as of 30 May 2020 (Worldometer, 2020). Also, the Trump administration, like the UK, was reluctant to implement harsh regulations, and the delayed and disjointed response in these two countries, according to experts, have aggravated the viral outbreak (Adalja et al., 2020).

The Peter G Peterson Foundation (2020) has rigorously researched figures and statistics from multiple US government departments and sources and provides an excellent summary of the parlous state of the USA economy, its national debt and, from our perspective, the investment in healthcare. What is beyond normality for the USA is they have not achieved universal healthcare coverage, and yet their military spend in fiscal 2018 was $\$ 649$ billion, which excludes any contingency fund. To put that into perspective, USA defence spending is larger than the combined spending of the next seven largest militaries, which is $\$ 609$ billion by China, Saudi Arabia, India, France, Russia, the UK, and Germany. How can a country morally spend over $\$ 600$ billion on military and defence and not provide universal healthcare for its citizens? Furthermore, as seen in Figure 3, the US government has spent over \$2.5 trillion on debt interest in the last decade, more than it did on any other national priority. How can this be right? 
FEderal SPENDING From FY2010 To FY2019 (BILLIONS OF DoLlaRS)

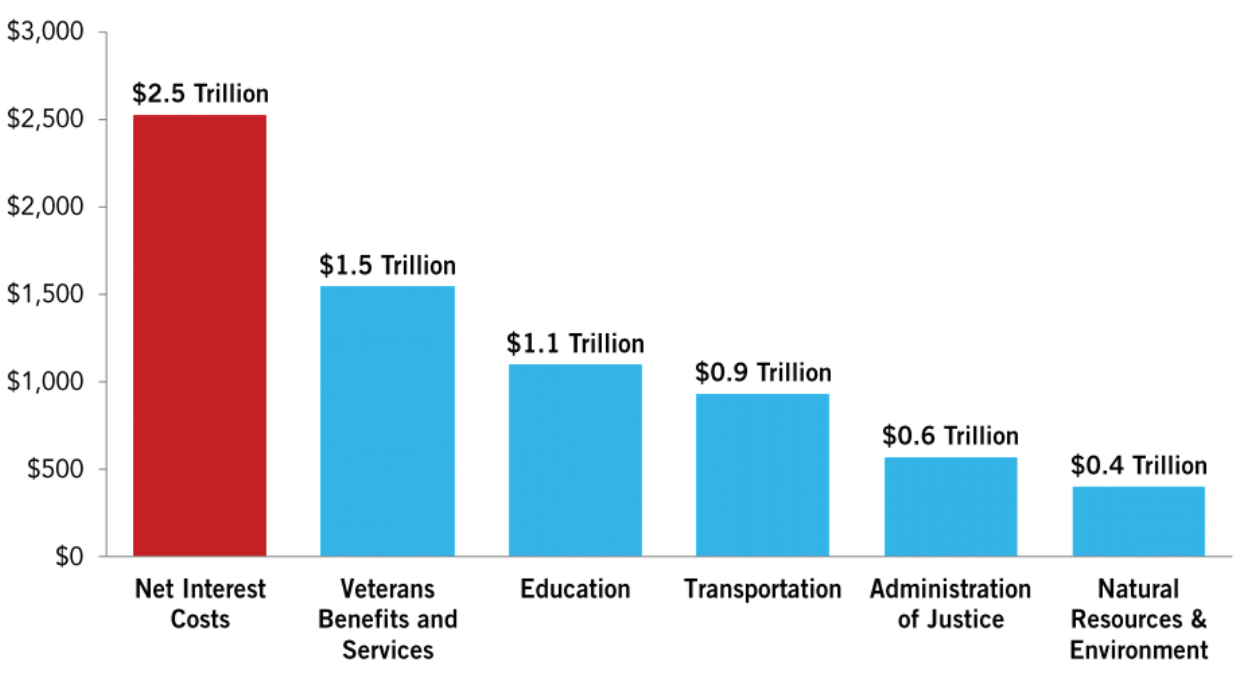

Figure 3 Federal Spending from FY2O10 to FY2019 (Billions of Dollars).

Source: Peter G Peterson Foundation, 2020.

Figure 3 informs us that the USA has spent more money on interest on its national debt than it did on national priorities. The USA has almost three times higher average cost per capita of healthcare at $\$ 10,586$, with the UK being $\$ 4,070$ and Germany being at $\$ 5,986$ (Peter G Peterson Foundation, 2020). This raises significant questions as to the economic policies that have been adopted where billions of dollars are spent on defence and trillions on servicing government debt rather than focusing on the healthcare needs of its citizens.

As with the UK, there are a plethora of reports, risk assessments, and operational plans that have been published by the CDC and other US government departments. Even a cursory reading of the significant number of reports would lead anyone to believe that the USA rightly deserves its premier place in the Global Health Security Index as noted in the introduction of this section. Three of the reports dated 2017 and 2019 tell the same story as the UK - that pandemic preparation is a top priority. A 2017 report titled Biological Incident Annex to the Response and Recovery Federal Interagency Operational Plans (January 2017), authored by Homeland Security, acknowledges that USA healthcare providers may "experience shortfalls in the availability of personnel, material, space, and systems required to meet the demands on medical and health systems during a biological incident, particularly a contagious disease outbreak" (Department for Homeland Security, 2017). This is a highly detailed report of 143 pages and by no means can we address it in its entirety. In essence, it is very similar to the 2011 UK preparedness report that we cited in the previous section.

There is a 2019 report titled Crimson Contagion 2019 Functional Exercise Key Findings report on the simulation carried out by the US Department of Health. We note that this report is a "coordinating draft", which was obtained by a straightforward search into Google search engine for "USA pandemic exercise reports". The report highlights that there are insufficient funding sources designated for the federal government to use in response to a severe influenza pandemic. Further, there was inconsistent use of terminology in respect of both the types of vaccines and the level of stockpiles; this was a source of confusion among response partners at all levels of government. Under the Resources section of the report, the conclusion drawn was that current medical countermeasure supply chain and production 
Vol. 7, No. 1, 9-45.

capacity cannot meet the demands imposed by nations during a global influenza pandemic (US Department of Health and Human Services, 2019).

Despite years of planning, Haffajee and Mello, writing in The New England Journal of Medicine, state that "COVID-19 has exposed major weaknesses in the United States' federalist system of public health governance, which divides powers among the federal, state, and local governments. SARS-CoV-2 is exactly the type of infectious disease for which federal public health powers and emergencies were conceived" (Haffajee and Mello, 2020). Their description of the response of the USA reflects the disjointed definition. Alarmingly slow and fostering confusion about the nature of the virus, with states and localities exercising their public health powers unevenly. Science-based social distancing and targeted quarantine measures can succeed only if implemented wherever the virus is spreading - the lack of inter-jurisdictional coordination has cost lives. There is widespread non-compliance with CDC-issued social distancing recommendations, despite dozens of localities issuing stay-athome orders, with some states only going as far as instructing non-essential businesses to close. Even with these orders, there is a lack of strong enforcement mechanisms (Haffajee and Mello, 2020). Despite the protestations by the current USA President, Donald Trump, the response of the United States is reflected in the statistics. It has the highest number of infections and the highest number of deaths.

\section{Germany preparedness and response}

Compared to many other countries, Germany's preparedness and response have managed the COVID-19 crisis swiftly and efficiently, owing to its properly funded health system, technological edge, and decisive leadership (Spahn, 2020). Germany's response has been based around a strategy of an aggressive track-and-trace process benefiting from a healthcare system that is fully invested and managed with long-term planning for a pandemic (World Health Organization, 2014). The track-and-trace strategy stalled the outbreak and prevented it from overwhelming the health system and, while at times German hospitals have been at breaking point, the foresight of long-term planning, in particular over the number of intensive care unit spaces (Spahn, 2020), has enabled Germany to save potentially tens of thousands of lives (Buranyi, 2020).

Germany's government-centric role in its economy, known as ordo-liberalism (which we will expand on in the next section), has enabled a greater preparedness and swifter response, which is combined with the foresight and vigilance of the German healthcare system. Fundamental to Germany's response and success is the distribution and sharing of power across the layers of governance, the Länder (state), the federal government, and civil society organizations. In healthcare, the federal and Länder governments traditionally delegate powers to membership-based, self-regulated organizations, which have mandatory participation but have autonomy in decisions on health and social matters (World Health Organization, 2014, p.17; Jowett, 2020). At the federal level, the Federal Assembly (Bundestag), Federal Council (Bundesrat), and the Federal Ministry of Health (Bundesministerium für Gesundheit) are the key actors in the healthcare system. Since 2014, the Federal Ministry of Health has been organized into six departments, which include a department whose sole focus is on public health services, communicable diseases, environmental hygiene, disaster preparedness, and civil emergency planning (World Health Organization, 2014, p. 43).

This has resulted in Germany having some of the lowest numbers of deaths globally, which as of 8 June 2020 was 8,690, with their number of infections being 186,109 - giving a fatality rate of $4.6 \%$; a stark contrast to the fatality rate of $14 \%$ for the UK (COVID-19 Dashboard by the Center for Systems Science and Engineering (CSSE) at Johns Hopkins University (JHU), 2020). According to a report by Rhodes et al. (2012), Germany's average number of ICU beds is the highest in the world, at 29.2 per 100,000, in marked contrast to 
the UK which has 6.6 beds per 100,00o. The average for Europe is 11.5 beds per 100,000 (Rhodes, et al., 2012). The actual number of ICU beds in Germany before the outbreak stood at 28,ooo, which was reportedly higher than the national requirement. After the outbreak, the German government initiated an increase to 40,0oo beds (Japan Medical Association, 2020), which is the primary reason Germany managed to reduce the death toll (Spahn, 2020). Measurement of what determines a successful pandemic policy response is the decline of new cases, and a consistent increase in recovered cases and COVID-19-related mortality rates per million people. As of 8 June 2020, Germany has the lowest rate of deaths per million people at 101.32, whereas the UK has 562.13 deaths and the USA 310.68. Most remarkably, as we turn to South Korea's response, their deaths per million figure is only 5.2 (Total confirmed COVID-19 deaths per million people, 2020).

\section{South Korea preparedness and response}

South Korea has had one of the best responses during the current pandemic. An analysis of six countries and their response to COVID-19 by the Council on Foreign Relations (CFR) found their response was swift, which is in marked contrast to the delayed and disjointed responses of the UK and the USA (Maizland and Felter, 2020; Patrick, 2020). As soon as South Korea had the genome sequencing of COVID-19, South Korean health authorities shared the data with medical research institutes and urged private biotech firms to develop diagnostic test kits (Lee, 2020). Like Germany, the government adopted a test-trace-treatment strategy, but with a difference. The government developed a plan to gather, investigate, and disseminate data, including the use of surveillance footage and credit card transactions to recreate patients' paths of infection measures; in the West, this would no doubt be seen as intrusive and a potential violation of privacy (Lee, 2020). This is an important topic and one that will need expanding in another paper, suffice to say, the price for the strategy was to save lives. South Korea has one of the lowest death ratios - at the time of writing the death toll is 273 deaths, with 11,814 confirmed cases (COVID-19 Dashboard by the Center for Systems Science and Engineering (CSSE) at Johns Hopkins University (JHU), 2020). The Korean state, like Germany, has a strong government role in healthcare, which is underpinned by central government control and delegated management. The Ministry of Health and Welfare has delegated the task of running the NHI to two quasi-public organizations - the National Health Insurance Service (NHIS) and the Health Insurance Review and Assessment Service (HIRA) - while retaining indirect control over it (World Health Organization, 2015, p. 43).

South Korea was deeply affected by the Middle East Respiratory Syndrome (MERS) in 2015, which resulted in heavy investment in emergency preparedness and designated the Ministry of the Interior and Safety as the main coordinator in health crises, rather than the prime minister or the president (Maizland and Felter, 2020). South Korea - where "bbalibbali", or "fast, fast", is a mantra - mobilised thousands of government officials, scientists, and medical personnel to avoid a repeat of the 2015 MERS pandemic. South Korea's strategy was to confront the challenge, employing technology as a public health tool in an aggressive campaign of testing, tracing, and tracking (Lee, 2020). Lee expands on this level of mobilizations by noting that:

disinfecting crews have been blanketing South Korea's trains, subways and crowded public plazas. The government is pushing out mobile phone alerts with details about confirmed cases and spots visited by those who tested positive; apps alert users when they are near potentially infected sites. Residents showing symptoms flock to drivethrough stations and mobile booths for quick, cheap tests, getting the results by text within hours. 
Vol. 7, No. 1, 9-45.

Experts have commended the country's quick efforts to "flatten the curve" and keep total deaths to some of the lowest in the world. After the first case appeared in January, the government rapidly developed a diagnostic test and tested millions of people for free. The UK is testing for free and private tests are also available, while the USA tests have several dependencies concerning testing, which means it might not be free (Radcliffe and Chesak, 2020). Many South Koreans have taken advantage of drive-through testing sites. The government designated specific hospitals for COVID-19 patients and required patients seeking other medical care to visit non-COVID-19 hospitals. Cha and Kim (2020) summarises South Korea's response in five key points: 1) early, 2) quick, 3) transparent, 4) Public-Private sector involvement, and 5) organization at the National level. It is the fifth point that is of note - the fact that the response was organized as a national effort rather than at the city, provincial, or local levels (Cha and Kim, 2020). We will argue in the next section that the UK could not adopt a South Korean strategy because it does not have the same level of central governance or management of healthcare (Hanage, 2020).

Sonn (2020) offers a most interesting and (depending on one's perspective) sinister reason for South Korea's success in combating COVID-19. Sonn acknowledges the positive impact that Korea's strategy has had on the country, going as far as to say that both South Korea and China arguably provide the best models for stopping outbreaks when large numbers of people have been infected. However, he argues that the reason why South Korea has been able to combat COVID-19 at speed is that the citizens are accepting of surveillance. He notes that there has been a lack of reporting of the country's significant use of surveillance technology, notably CCTV and the tracking of bank card and mobile phone usage. Sonn notes that South Korea has the highest proportion of cashless transactions in the world, and that tracking transactions, it's possible to draw a card user's movements on the map and, therefore, has enabled South Korea to execute its track and test strategy - what Sonn describes as "test, test and test some more" (Sonn, 2020). Sonn's perspective is contrasted with the west when he writes:

The difference between the South Korean approach and that of European countries doesn'trepresent thesimpleclichéof eastern collectivism versus western individualism. Information exposure can prevent the need for a lockdown of individuals' movements. In this way, governments around the world are facing a hard choice between these two violations of individual rights (information exposure and movement restriction). South Korea has chosen the former, but France and Italy had to choose the latter. The former requires the necessary infrastructure and a culture that tolerates a certain level of surveillance, neither of which can be created overnight.

(Sonn, 2020)

Sonn touches on a very important topic, and by no means expands on it, but a future study would have value if it were to consider whether surveillance is the key to fighting a pandemic, although the political and personal implications for the West, in particular, leaves many unanswered questions.

\section{Neoliberalism $v$ mixed economy and the global shift}

The response of the UK and USA has been weaker than that of Germany and South Korea as all the statistics on every level prove. The responses of each of the countries have a dependency on their healthcare system, their level of preparedness, and the speed at which they have been able to deal with the pandemic. As we have discussed in the previous sections, Germany and South Korea have in common a significant level of government investment and funding into their healthcare systems.

More fundamental is how both countries have direct government control of their economy. The UK and USA both have free-market economics and, as we have already argued 
and evidenced, this leaves any industry and marketplace open to privatization and deregulation. The UK has privatised billions of pounds of services and has cut services under an austerity programme for the last ten years whilst the US's hybrid system of single-payer health insurance and multi-payer universal health insurance fund is profit-driven, and so the private-sector healthcare providers put profit before people, and the state puts politics before people when it comes to healthcare (Riley, 2012; Wilensky, 2012; Barrilleaux and Rainey, 2014).

Conventionally, neoliberalism is associated with buccaneering deregulation, especially of financial markets, and a weak state. Even if this is accepted and the argument holds, the "retreat" of the state is, in reality, a transformation of the state towards a "competitive" state, that is a market enforcing and embedding state (Bonefeld, 2012). The UK and USA have competitive economies and their focus on deregulation and small (read weak) state has resulted in the UK and USA heading the highest COVID-19 infection and death tolls globally. Germany and South Korea's statistics are almost the opposite. Why is this? As we have noted earlier, the UK, Germany, and South Korea have an almost identical populous, so our comparison and contrast have relevance. We argue that the UK and USA have reduced the level of state control and intervention and, in doing so, have diluted their manufacturing output. Both countries have had decades of deregulation and privatization, with cuts to public services as we have already referenced.

Between 1965 and 2000, US manufacturing employment fluctuated around 18 million workers, although between 1979 and 2000 there was a drop of over 12 per cent, which then plunged even further to 25 per cent from 2000 to 2012 . This reduction in manufacturing coincided with the USA granting Permanent Normal Trade Relations (PNTR) to China and became effective upon China's accession to the World Trade Organization (WTO) at the end of 2001 (Pierce and Schott, 2016; Fort, Pierce, and Schott, 2018). Fort, Pierce, and Schott seek to answer the question of whether the decline is, in part, due to computing technology, automation, and robotics. They find that 'before 2000, the drop in manufacturing firms' manufacturing employment is more than offset by increases in non-manufacturing workers. After 2000, a sharp decline in those firms' manufacturing employment and a flattening of their non-manufacturing employment growth leads to a decrease in their total employment" (Fort, Pierce, and Schott, 2018). Their research shows that 75 per cent of the 6.6 million manufacturing jobs that were lost between 1979 and 2012 were not from companies going bankrupt but took place within continuing firms, largely from plant closures. They close their paper with some compelling questions, with a core question of what barriers to entry there were for 69 firms to dampen creation or suppress firm destruction.

Germany's economy is based on what is known as ordoliberal economics that is "oriented toward the supply side and the social market economy, that was progressively reinforced - both institutionally and ideologically - over succeeding stages in the post-war period" (Allen, 2005). As Allen succinctly notes, Keynesian ideas and policies were widespread across the majority of the developed capitalist world following WW2, and yet were strangely and uniquely absent in Germany. German economists and policymakers sought to "return to an institutional pattern with roots in the late nineteenth century in which the state established a general framework for a powerful and self-regulating private sector" (Allen, 2005). The emphasis of Allen's argument is that it was the German state that establishes the framework for the self-regulating private sector, not the market itself self-regulating. Bonefeld is helpful on the definition of ordoliberalism, which he describes as a progressive alternative beyond left and right. Ordoliberalism is conceived of as a socially responsible political economy that, in contrast to neoliberal ideas of free markets, is not a market economy at all. In his view, it amounts to a socially responsible form of government that protects individuals from the homogenization and strife that free markets bring about (Bonefeld, 2020). Ordoliberalism has enabled Germany to be the largest European economy, the fourth 
Vol. 7, No. 1, 9-45.

largest manufacturing producer globally, the second largest manufacturing exporter after China, the third-largest commercial services exporter, and the third most important source of Foreign Direct Investment (FDI) (Dicken, 2011, p. 27).

South Korea's economic history, up until the 1960 , is described as a backward, desolate economy based on subsistence agriculture with a society that was traditional, feudalistic, agrarian, and isolated from the West until the late nineteenth century (Kim, 1991). From this background, South Korea's economy grew, on average, from 1963 at six per cent per annum until 1997 and turned the country from an agrarian state to one of the most developed countries in the world. One of the reasons for this economic miracle (as it has been termed) is the active role(s) that the government has played in the economy. Unusually, a succession of military regimes has chosen appropriate economic policies and, more importantly, have been able to implement them. We use the word "unusual" because often political constraints limit the choice of policy and implementation is often undermined by weak administration.

The wide-ranging economic reforms established by General Park in 1963 were based on a mix of market incentives and state direction, together with a highly repressed financial market where domestic savings (plus international aid) financed capital accumulation. To adopt a rigorous industrial policy and build the foundation for a manufacturing-based economy, the government guided financial system behavior, with (national) banks directing funds to the productive sector (Kuznets, 1985; Kim, 1991; Eich-Born and Hassink 2005; Stanley 2008). As we have noted earlier in this section, South Korean healthcare investment was a key priority for successive governments, with universal healthcare being achieved in 1989 .

COVID-19 has been a pandemic that has demonstrated that a shift in the process of industrialization does have significant geographical implications, and part of this is that both Germany and South Korea have been able to meet their own healthcare needs and had high-level of preparedness for their citizens. Germany and South Korea are the product of ambitious industrialization policies implemented by consecutive national governments.

\section{Systemic weakness of neoliberalism}

To allow the market mechanism to be the sole director of the fate of human beings and their natural environment indeed, even of the amount and use of purchasing power, would result in the demolition of society.

$$
\text { (Polanyi, [1944] 2001, pp. 76-77) }
$$

\section{Introduction: core competence}

In their seminal paper, The Core Competence of the Corporation, Prahalad and Hamel describe competence as the combination of resources and skills, and is communication, involvement, and a deep commitment to working across organizational boundaries, involving many levels of people and all functions. Such core competencies are crucial for the successful running of an effective government and are essential when handling a crisis such as a pandemic.

In contrast to Prahalad and Hamel's paper, Miller (1992) also writes a seminal article titled The Icarus Paradox: How Exceptional Companies Bring About Their Downfall (Miller, 1992). The essence of Miller's argument is that something pushed to excess will fail. Miller posits that "it is ironic many of the most dramatically successful organizations are so prone to failure. The histories of outstanding companies demonstrate this time and time again. It appears that when taken to excess, the same things that drive success . . . also, cause decline" (Miller 1992). Miller continues his argument by stating that overconfidence and complacency result in success turning to failure. In this section we will use Miller's principle that 
something pushed to its extremity will fail. We will argue that the Great Recession in 2008 is a prima facie case of banking and finance pushed to its extremities bringing about catastrophic failure. Not only did neoliberalism fail in 2008, but it also failed individuals and small businesses, and arguably led to a greater imposition of neoliberal policies in the guise of austerity measures across Europe (Stuckler et al., 2017). This led to deeply personal, financial, emotional, mental, and physical damage to well-being of individuals in the UK and USA as lives were blighted and economic hardship became the norm (Loopstra et al., 2016; Stuckler et al., 2017). Our primary argument is that a "domino effect" was created from the 2008 financial crash, which 12 years later led directly to the UK's lack of preparedness when COVID-19 impacted; this is in stark contrast to Germany and South Korea.

To evidence our argument, we will firstly offer a brief overview of two opposing economic ideologies to identify the inherent weakness of neoliberalism and free-market economics. Secondly, we will discuss how the financial crash of 2008 led to a change in government in the UK, which in turn led to the implementation of austerity measures. Thirdly, in discussing the austerity measures, we will evidence and argue how the cuts to public services, in particular, led to the UK's lack of preparedness when the COVID-19 pandemic hit in January 2020. In discussing neoliberalism, we will compare and contrast this with all of the four countries under discussion and show how there has been a significant global shift from the West to the East, which has undermined the West and strengthened the East.

Dicken summarises 250 years of the economic global shift between the West and the East, writing that:

in 1700, Asia dominated; its share of global GDP was 62 per cent compared with the West's 23 per cent. But by 1950 those positions had been almost exactly reversed: the combined share of global GDP of Western economies was almost 6o per cent; that of Asia (including Japan) was a mere 19 per cent. Much of this was due to the relative economic decline of China and India. In 1700, their combined share of global GDP was almost 50 per cent; by 1950, it had plummeted to less than 10 per cent. They had become totally peripheral. Today, the picture is very different. East Asia is back.

(Dicken, 2011, p. 16)

\section{Government or governance? Keynesian economics}

Foucault describes the art of government as "essentially concerned with answering the question of how to introduce economy" (Foucault, 1991, p. 92). Foucault continues to postulate that "to govern a state will, therefore, mean to apply economy, to set up the economy at the level of the entire state" (Foucault, 1991, p. 92). Without getting into a detailed counter-discussion, neoliberalism (free-market economics) is the diametrically opposite economic theory that has prevailed since $\mathrm{WW}_{2}$, primarily that of state management and control of industry. John Maynard Keynes is considered the most influential economist in British history and was considered to have a flexible approach to both economic theory and practical politics. Short-term gain to serving people and their needs should take priority over longer-term economic theory (Jones, 2014, p. 182). Jones notes that "John Maynard Keynes towered over economic policy in the twentieth century" (Jones, 2014, p. 182). Keynes argued that economic theory had not been able to adequately explain the Great Depression of the 1930 and so "spearheaded a revolution in economic thinking that overturned the then-prevailing idea that free markets would automatically provide full employment" (International Monetary Fund, 2014).

Keynes' primary assertion was that spending by households, business, and the government is the most important driving economic force, and he argued that raising consumer demand is critical in a depressed economy. To do this, there is a need for the government to boost production and stimulate the economy with expenditure and investment, even if this 
Vol. 7, No. 1, 9-45.

meant increased public debt. This would halt the decline that had come about through the lack of private investment in the economy and, therefore, the Government had to intervene (Jones, 2014, p. 184). The most significant government intervention would be in public works and investment in infrastructure projects, which would, according to Keynes, "beat the business cycle through fiscal policy or large-scale public investment when demand in the economy was either sluggish or in recession" (Jones, 2014, p. 25). Palley notes that it was during this era of 1945-1970 in which the "modern tools of monetary policy and fiscal policy were developed" (Palley, 2005, p. 21).

The purpose of contrasting "Keynesian economics" with "Chicago school" economics is the relationship the role of government has in their approach to economics, which is fundamental to the arguments of this paper. The USA and the UK systematically and comprehensively eroded the Keynesian assumptions that had underpinned post-war economic and social policy, a fiscal retrenchment project of colossal proportions (King and Wood, 1999, p. 371). King and Wood continue their argument, noting that "the policies of the Reagan and Thatcher administrations can simply be 'read-off' from the tenets of the ideology that underpins them" (King and Wood, 1999, p. 372). The adoption of neoliberalism was a prima facie rejection of Keynesian, with specific emphasis on the rejection of the role of the state and organised interests in the economic governance (King and Wood, 1999, p. 372).

We argue that the rejection of government intervention, state control, and regulation through the 1980 s, and subsequent two decades into the early 2000 , ultimately led, as Miller argues, to a failure of an ideology. This failure firstly in the inequality between the haves and the have-nots (The haves and have-nots definition and meaning | Collins English Dictionary, 2020) and the second failure, which has led to the increase in globalization which, in turn, has led to a global shift from the West to the East. Before we expand on this argument, we need to place neoliberalism in the context of "Chicago school" economics.

\section{Government or governance? "Chicago school" economics}

In moving then to the discussion on neoliberalism, we will first outline the principles through the works of Freidrich Hayek (1960) and Milton Friedman (1962). We then look at how neoliberalism was implemented in the USA and UK and contrast this with Germany and South Korea. We use the term "Chicago school" economics as the dominance of neoliberalism and free-market economics ideology came from the heavily mythologised academic environment of the Department of Economics at the University of Chicago. Klein notes that this department saw itself as more than a school, it was a school of thought whose ideas represented a revolutionary bulwark against the dominant "statist" ideas (Klein, 2008, p. 49).

A helpful starting point on neoliberalism is the book review by Francis Fukuyama (2011) for The New York Times for F.A. Hayek's updated influential book Constitution of Liberty. Fukuyama notes that several economists have, over time, come to accept several of Hayek's ideas on the balance between government control and free markets. Fukuyama states the Hayek was of the view that:

labor unions create a privileged labor sector at the expense of the nonunionized; that rent control reduces the supply of housing; or that agricultural subsidies lower the general welfare and create a bonanza for politicians. His view that ambitious government-sponsored programs often produce unintended consequences served as an intellectual underpinning of the Reagan-Thatcher revolution of the 1980 os and ' 90 os.

(Fukuyama, 2011) Hayek and Friedman argued against "big government" and their primary message was freedom and liberty, that is, economic and political freedom (Hayek, 1960; Friedman, 1962). Hayek argued that the modern economy was more local, and that no government can know enough about a society in total to plan effectively. The government's true role is more modest: 
to create laws that are general and equally applied; these laws constitute the matrix in which the spontaneous interactions of individuals can occur (Fukuyama, 2011). While the existence of a free market does not eliminate the need for government or governance, the purpose of government is both as a forum for determining the "rules of the game" and to act as an umpire or referee to both interpret and enforce the rules (Friedman, 1962, p. 21).

Milton Friedman's free-market economics is based on the principle of "small state" that manages the "rules of the game" in-line with what Foucault would call, "less government, not less governance" (Rose and Miller, 1990). While this is an important distinction, we would argue that it was precisely the lack of governance that led to the financial crash of 2008. There are almost too many scholars, academics, and commentators to reference and evidence this statement, and far more questions than answers - one would scarcely know where to start. There is a deluge of official reports, documentaries, official enquiries, and senate committee investigations all of which affirmatively validate the claim we assert above. The Financial Crisis Inquiry Report, the official US Government report on the crash of 2008, concluded the following:

We conclude widespread failures in financial regulation and supervision proved devastating to the stability of the nation's financial markets. The sentries were not at their posts, in no small part due to the widely accepted faith in the self-correcting nature of the markets and the ability of financial institutions to effectively police themselves.

(The Financial Crisis Enquiry Commission, 2011)

\section{The case against neoliberalism}

Neoliberalism, fundamentally, is about separating government from the markets and this, we argue, is what is the systemic weakness and inherent flaw in this ideology. The COVID-19 pandemic compels governments and citizens alike to understand the vital importance of the public realm, of public services and the direct influence and impact they have on each without exception. As Keynes himself argued, governments should solve problems in the short run. We would all be dead in the long run if we leave market forces to fix things (IMF, 2014). When we look at the debris in the aftermath of the financial crash of 2008 , it was government intervention that saved the deregulated banking industry, even though it was the banks who were the cause of the crash (Centeno and Cohen, 2012; Stiglitz, 2015). We noted in the previous section that when there is a crisis, Keynesian economics requires government intervention and it is extraordinary how many "free-market" companies are looking to the government as the solution to the loss of revenue.

Friedman strongly argued that there is an "intimate connection between economics and politics" (Friedman, 2002, p. 8). He argues that economic arrangements promote a free society in two ways. Firstly, it is a component of freedom as a general principle, but secondly, it is an indispensable way of achieving the goal of political freedom. Where there is economic and political freedom, the markets are free, it is, therefore, tautological that there will be a free society. Klein also points out a fundamental flaw is that "Friedman could not point to any living economy that proved that if all 'distortions' were stripped away, what would be left would be a society in perfect health and bounteous since no country in the world met the criteria for perfect laissez-faire" (Klein, 2007, p. 51). Friedman himself confesses that no one can tell if this doctrine will become victorious (Peck, 2010, p. 4). Citing Peck in his book Political Economy and Sociolinguistics, Block notes that "neoliberalism is more of an ill-defined amalgam of ideas in motion (which are, nonetheless, highly ideological) than a tidy, coherent package" (Block, 2017, p. 53). As he puts it, neoliberalism is "a contradictory process of market-like rule" organized around a vague notion of laissez-faire and opposition to all policies and practices associated with "Keynesian economics". 
Vol. 7, No. 1, 9-45.

What Friedman is postulating is that a free market has as its purpose the goal of greatly reducing the number of issues that must be agreed or decided on through political or governmental means. This, in turn, limits the "extent to which the government needs to participate directly in the game" (Friedman, 1962, p. 21). Friedman had an inherent belief in the disciplinary mechanism of the market and sovereignty of the consumer (Chernomas and Hudson, 2017, p. 66). This belief, however, has damaged whole industries in the UK and USA, and has negatively impacted the lives of individuals, towns, and cities as deregulation, privatization, and globalization destroyed value. An example is found close to home, as the authors of this paper studied at Keele University, less than five miles from the great industrial city of Stoke-on-Trent - a city once dominant with coal, tyre, steel, and its world-leading pottery industry. Yet between 1975 and 1990, 32,00o jobs were lost when 36 factories closed, along with coal pits and steel foundries. Pottery dynasties from Stoke-on-Trent produced $90 \%$ of British Pottery and accounted for $70 \%$ of all pottery ware entering world export markets, and all of this was lost permanently (Imrie, 1991; Ridge, 2002).

In the UK and USA there have been multiple recessions, varying from six months to nineteen months between 1979 and 2011 (Hoynes, Miller, and Schaller, 2012). The destruction of industries and the constant cycle of recessions under free-market economics is a recurring position, as markets fail due to the "domino effect" that we referenced earlier. "Chicago school" economics always leads to a reduction in direct government investment. It transfers that control to the private sector, and what we have today is whole industries, markets and, in particular, healthcare, controlled by corporations or individuals solely for profit. After the 2008 financial crash, self-declared centrist and MIT economic legend Paul Samuelson crowed, "today we see how utterly mistaken was the Milton Friedman notion that a market system can regulate itself" (Chernomas and Hudson, 2017, p. 67). It is this point that leads us to the case against neoliberalism and its systemic weaknesses and inherent failure in the last three decades.

As we are witnessing during the COVID-19 crisis, businesses from all sectors are struggling and are receiving financial support from their respective governments. However, whilst the support offered is arguably earned by tax-paying and lawfully operating companies, many companies who do not pay tax in the UK are still seeking the UK government's support. Virgin Atlantic airline asked the UK government for a bailout despite being $51 \%$ owned by a tax-exile, Richard Branson. While some countries, including France, Denmark, and Poland are refusing to bail out companies who avoid paying tax in their countries, the UK is not following suit (BBC, 2020).

We use Richard Branson as an example as he is a high-profile individual in the UK, and yet we could fill multiple pages of businessmen who believe in the free-market but seem to believe that in a crisis it is the job of the government to bail them out. The banks in 2008 ? Free-market greed, short-term profit, and hubris led to a crash not seen since the 1930s, and yet in the USA and the UK the government was expected to solve the problem. It is the temerity of expectation that government grants and bailouts are needed when it suits these free-market business leaders that ought to create a problem for policymakers. While COVID19 is not the fault of businesses, the responsibility for a global catastrophe is rarely (if ever) planned for, and this is part of the problem with free-markets. Short-term profit focus on revenue, profit, and share prices, which are more important than long-term investment and focus on employees.

\section{Conclusion: why the lack of preparedness?}

We set out to research why there was such disparity between the responses of the UK and USA to COVID-19 when compared to the remarkably superior approaches and consequences of Germany and South Korea. Our research has taken us deeper than we anticipated, the 
reports, risk assessments, and planning documentation from both the UK and USA governments surprised us. Our analysis left us with one conclusion: decades of a global shift from the West to the East, deregulation, privatization, and public sector cuts have resulted in healthcare systems that do not accurately reflect the GHS Index 2019 report.

We need to acknowledge that when we consider the healthcare systems, we are referring to the systems and structures, not the personnel. We applaud all healthcare workers, in particular in the UK and USA, whose commitment, dedication, and risk to personal health across the hospitals, surgeries, and care homes have saved lives. Successive UK governments have left the NHS underfunded and bereft of resources, and yet, nurses, doctors, and clinicians have taken an enormous risk to ensure that those who have been infected by COVID-19 are given the best opportunity to recover. We would argue that the efficacy of their work is down to local staff delivering in a time of crisis, and not due to any great input by the government.

With over £330 billion of government support for businesses (Sharma MP and Sunak MP, 2020), there is proof that neoliberalism is a flawed theory. This is an extraordinary sum of money considering the cost of funding the UK National Health Service (NHS) for 2018/19 was $£ 129$ billion. Deregulation and privatization have not led to saving money or led to "small" government; rather it is the opposite, with the UK government increasing national debt just to "keep the ship afloat". Is it not a tautological argument that investment in healthcare in the last decade, rather than austerity, would have saved billions of pounds, and at a lower cost to the lives of individuals?

The evidence of the crash of 2008 and the COVID-19 response proves that neoliberal deregulation leads to the opposite of the freedom that "Chicago school" economics postulates. At the time of writing, there are approximately 3.2 billion global citizens in lockdown (Bucholz, 2020), that is global citizens unable to leave their homes. We have argued that deregulation in the UK and USA has led to inequality, profit before people, and has led to their inability to prepare for a pandemic, in sharp contrast to Germany and South Korea. "Just as the financial crash was treated as the malfunctioning of a particular unsupervised bug in the system rather than as a feature of it, so is the failure to grapple with the pandemic being cast as an unforeseen, exogenous event, rather than a result of an ideology that enables the state to scramble unprecedented resources to save banks but not lives" (Malik, 2020).

New policies need to be adopted by the UK and USA governments. Neoliberalism's dominance comes from the unwillingness to adopt alternative options, or maybe even the absence of them. In many sectors corporations have the power to raise prices, have market power and political power, securing legislation and lobbying for changes to suit their profitdriven agendas (Stiglitz, 2015).

The Egyptian economist Samir Amin argues for a "national sovereign project", which is centred on a "set of consistent national policies aimed at 'walking on two legs': (1) constructing an integrated, auto-centred industrial system of production; (2) moving toward policies to revive and modernize peasant agriculture; and (3) articulating these two goals into a consistent, comprehensive plan of action" (Amin, 2017). Some would baulk at the term "peasant agriculture", but in the name of "free-markets" the UK citizen can buy a pint of milk for $£ 1.20$ while farmers who produce the milk have seen their industry destroyed - in 2019/20 making just 3.4p per litre profit (UK Farming News, 2019). Amin's 2013 paper, Audacity, More Audacity, offers a concrete example of what could be involved in the socialization of what he calls, "capitalist" farmers of the North and "peasant" farmers of the South (Amin, 2013). What Amin is arguing is what we have sought to establish in this paper. Government, or "sovereign national projects", must surely be the basis of economic policy, rather than the outdated, flawed neoliberalism. The UK government must adopt new policies that engage with the market and ensure that the fabric of society is not weakened as a 
Vol. 7, No. 1, 9-45.

result of the lack of preparedness. We would support any national sovereign policy that has the UK returning to its base of both manufacturing and agriculture.

The alternative would be to misquote Louis Pasteur and say that unless we do, it is the microbes who will have the last word.

\section{Notes}

${ }^{1}$ Keele University. BA (Dual Hons) International Business \& International Relations, LLM International Law \& Politics 2015-2019.

${ }^{2}$ Keele University. BA (Dual Hons) Politics and History, 2015-2018. MSc in Gender, Peace and Security, London School of Economics, 2020-2022.

${ }^{3}$ Keele University, BA (Dual Hons) International Business \& International Relations, 2015-2018. University of Exeter, MSc International Management, 2018-2019. University of Exeter, PhD Candidate Political Economy, 2020-2024.

\section{Bibliography}

3M United Kingdom (2020). Guide to The PPE Regulation (EU) $2016 / 425 \mid 3 M$ United Kingdom [online] 3m.co.uk. Available at: <https://www.3m.co.uk/3M/en_GB/workerhealth-safety-uk/resources/guide-ppe-regulation/> [Accessed 8 June 2020].

Abdelbaqi, S. (2014). Novel engineered cationic antimicrobial peptides have a broad-spectrum activity against: Francisella tularensis, burkholderia pseudomalli and yersinia pestis (Doctoral dissertation, University of Pittsburgh).

Adalja, A. A., Toner, E., and Inglesby, T. V. (2020). Priorities for the US health community responding to COVID-19. Jama, 323(14), 1343-1344.

Adams, R. (2006). Milton Friedman: a study in failure. The Guardian [online]. Available at: <https://www.theguardian.com/commentisfree/2006/nov/16/post65o> [Accessed 17 May 2020].

Alchon, S. A. (2003). A pest in the land: new world epidemics in a global perspective. UNM Press.

Algaze, G. (2018). Entropic cities: The paradox of urbanism in ancient Mesopotamia. Current Anthropology, 59(1), 23-54.

Allen, C. (2005). "Ordo-Liberalism” Trumps Keynesianism: Economic Policy in the Federal Republic of Germany and the EU1. In: Bernard H. Moss, ed., Monetary Union in Crisis. London: Palgrave Macmillan, pp. 199-221.

Allen, R. (2011). Why the industrial revolution was British: commerce, induced invention, and the scientific revolution. The Economic History Review [online] 64(2). Available at: <https://www.jstor.org/stable/41262428> [Accessed 16 May 2020].

Amin, S. (2013). Audacity, More Audacity. Review of Radical Political Economics, 45(3), 400-409.

Appleby, J. (2015). UK NHS: Less money (but more bangs per buck)? BMJ, 350(mar1o 16), h1037-h1037.

Baily, M. and Bosworth, B. (2014). US Manufacturing: Understanding Its Past and Its Potential Future. Journal of Economic Perspectives, 28(1), 3-26. 
Bale, T. (2017). The Conservative Party: From Thatcher to Cameron. John Wiley \& Sons.

Barrilleaux, C. and Rainey, C. (2014). The Politics of Need: Examining Governors' Decisions to Oppose the "Obamacare" Medicaid Expansion. State Politics \& Policy Quarterly, 14(4), 437-46o.

BBC News. (2020). Branson's Virgin Atlantic In Virus Bailout Talks [online] Available at: <https://www.bbc.co.uk/news/business-52431290> [Accessed 21 May 2020].

Block, D. (2018). Political Economy and Sociolinguistics Neoliberalism, Inequality and Social Class. 1st ed. London: Bloomsbury Academic.

Bonefeld, W. (2012). Freedom and the Strong State: On German Ordoliberalism. New Political Economy, 17(5), 633-656.

Bray, R. S. (2004). Armies of pestilence: the impact of disease on history. Cambridge: James Clarke \& Co.

Bruun, C. (2007). The Antonine plague and the 'third-century crisis'. In Crises and the Roman Empire (pp. 201-217). Leiden and Boston, MA: Brill.

Buchholz, K. (2020). Infographic: What Share of The World Population Is Already On COVID19 Lockdown? [online] Statista Infographics. Available at: <https://www.statista.com/ chart/21240/enforced-covid-19-lockdowns-by-people-affected-per-country/> [Accessed 16 May 2020].

Buranyi, S. (2020). Inside Germany's Covid-19 testing masterclass. Prospect [online] Available at: <https://www.prospectmagazine.co.uk/magazine/germany-covid-19-masterclass-testingtracing-uk> [Accessed 27 May 2020].

Cdc.gov. (2020). National Pandemic Influenza Plans | Pandemic Influenza (Flu) | CDC [online] Available at: <https://www.cdc.gov/flu/pandemic-resources/planning-preparedness/national-strategy-planning.html> [Accessed 6 June 2020].

Centeno, M. and Cohen, J. (2012). The Arc of Neoliberalism. Annual Review of Sociology, 38(1), 317-340.

Center for Disease Control and Prevention. (2020). 2009 HiN1 Pandemic [online] Available at: <https://www.cdc.gov/flu/pandemic-resources/2009-hını-pandemic.html> [Accessed 29 May 2020].

Cha, V. and Kim, D. (2020). A Timeline of South Korea's Response To COVID-19 [online] Csis.org. Available at: <https://www.csis.org/analysis/timeline-south-koreas-responsecovid-19> [Accessed 12 May 2020].

Chaudhuri, S. (1996). Government and Economic Development in South Korea, 1961-79. Social Scientist, 24(11/12), 18.

Chen, W. H., Strych, U., Hotez, P. J., and Bottazzi, M. E. (2020). The SARS-CoV-2 vaccine pipeline: an overview. Current tropical medicine reports, March 3, 1-4.

Cherkaoui, M. (2020). Responding to Kissinger: The Risks of Remodelling Neoliberalism and Manipulating the Enlightenment values. Aljazeera Studies, April 26.

Chernomas, R. and Hudson, I. (2017). The Profit Doctrine: Economists of The Neoliberal Era. London: Pluto Press.

Choice Reviews Online. (2015). Oxford Arabic dictionary: Arabic-English/English-Arabic. 52(07), 52-3403-52-3403. 
Vol. 7, No. 1, 9-45.

Chomsky, N. (2020). Noam Chomsky: In Response to Coronavirus, "You Can Do Something". Jacobin [online] Available at: <https://jacobinmag.com/2020/4/noam-chomsky-coronaviruspandemic-trump $>$ [Accessed 15 May 2020].

Civil Contingencies Act 2004. (2004) Chapter 36. Available at: <https://www.legislation.gov. uk/ukpga/2004/36/pdfs/ukpga_20040036_en.pdf> [Accessed May 2020].

Collinsdictionary.com. (2020). The Haves and Have-Nots Definition and Meaning | Collins English Dictionary [online] Available at: <https://www.collinsdictionary.com/dictionary/ english/the-haves-and-have-nots> [Accessed 20 May 2020].

Consultancy.uk. (2020). UK And US Mishandle Covid-19 Despite Supposed Preparedness [online] Available at: <https://www.consultancy.uk/news/24211/uk-and-us-mishandlecovid-19-despite-supposed-preparedness $>$ [Accessed 20 May 2020].

COVID-19 Dashboard by the Center for Systems Science and Engineering (CSSE) at Johns Hopkins University (JHU). (2020). COVID-19 Dashboard by The Center For Systems Science and Engineering (CSSE) At Johns Hopkins University (JHU) [online] Available at: <https:// www.arcgis.com/apps/opsdashboard/index.html\#/bda759474ofd40299423467b48egecf6> [Accessed 13 May 2020].

Covid-19 News. (2020). Covid-19 News: Johnson Admits UK Was Unprepared for Pandemic [online] New Scientist. Available at: <https://www.newscientist.com/article/2237475-covid19-news-johnson-admits-uk-was-unprepared-for-pandemic/> [Accessed 30 May 2020].

Davies, J. and Blanco, I. (2017). Austerity urbanism: Patterns of neo-liberalisation and resistance in six cities of Spain and the UK. Environment and Planning A, 49(7), 1517-1536.

De Haan, D. D. (2018). Avicenna's Healing and the Metaphysics of Truth. Journal of the History of Philosophy, 56(1), 17-44.

Department for Homeland Security. (2017). Biological Incident Annex to The Response and Recovery Federal Interagency Operational Plans (January 2017). Washington, DC: Department for Homeland Security.

Department of Health. (2020). NHS Property and Estates: Why the Estate Matters for Patients. London: Department of Health.

Department of Health, Cabinet Office, Health Protection Agency. (2007). Exercise Winter Willow: Lesson Identified. London: Department of Health.

Dicken, P. (2011). Global Shift: Mapping the Changing Contours of The World Economy. 6th ed. New York, NY: The Guilford Press.

Dintenfass, M. (1992). The Decline of Industrial Britain: 1870-1980. 1st ed. London, UK: Routledge.

Edwards, C. (2017). Margaret Thatcher's privatization legacy. The Cato Journal [online] 37(1). Available at: <https://www.cato.org/sites/cato.org/files/serials/files/cato-journal/2017/2/cjv37n1-7.pdf> [Accessed 3 May 2020].

Eich-Born, M. and Hassink, R. (2005). On the Battle between Shipbuilding Regions in Germany and South Korea. Environment and Planning A: Economy and Space, 37(4), 635-656.

Fairclough, I. (2015). Evaluating policy as an argument: the public debate over the first UK austerity budget. Critical Discourse Studies, 13(1), 57-77.

Fort, T., Pierce, J., and Schott, P. (2018). New Perspectives on the Decline of US Manufacturing Employment. Journal of Economic Perspectives, 32(2), 47-72. 
Foucault, M. (1991). Governmentality. In: G. Burchell, C. Gordon and P. Miller, ed., The Foucault Effect. Hemel Hempstead, UK: Harvester Wheatsheaf, pp. 87-118.

Fouskas, V. and Gökay, B. (2020). COVID-19 And the Bankruptcy of Neoliberalism In The Context Of Global Shift [online] openDemocracy. Available at: <https://www.opendemocracy.net/en/can-europe-make-it/covid-19-and-bankruptcy-neoliberalism-context-globalshift/> [Accessed 25 May 2020].

Frade, C. (2020). Pandemic Politics, Oligarchic Times and The Idiotic Subject Of 'Freedom' [online] openDemocracy: free thinking for the world. Available at: <https://www.opendemocracy.net/en/democraciaabierta/pandemic-politics-oligarchic-times-and-the-idioticsubject-of-freedom/> [Accessed 21 May 2020].

Friedman, M. (1962). Capitalism and Freedom. Chicago: The University of Chicago Press.

Fukuyama, F. (2011). Friedrich A. Hayek, Big-Government Skeptic. The New York Times [online] Available at: <https://www.nytimes.com/2011/o5/o8/books/review/f-a-hayek-biggovernment-skeptic.html?auth=login-facebook> [Accessed 12 May 2020].

Full Fact. (2019). Spending on The NHS In England [online] Available at: <https://fullfact. org/health/spending-english-nhs/> [Accessed 21 May 2020].

GHRF Commission. (2016). The Neglected Dimension of Global Security: A Framework to Counter Infectious Disease Crises. [eBook] Washington, DC: National Academies Press. Available at: <http://nam.edu/GHRFreport.doi> [Accessed 7 May 2020].

Gilroy, R. (2020). Nurses raise alarm after practices sent PPE with altered expiry date. The Nursing Times [online] Available at: <https://www.nursingtimes.net/news/coronavirus/nurses-raise-alarm-after-practices-sent-ppe-with-altered-expiry-date-17-03-2020/> [Accessed 3 June 2020].

Global Health Security Index. (2019). 2019 Global Health Security Index. Global Health Security Index [online] Washington, DC: Nuclear Threat Initiative (NTI) the Johns Hopkins Center for Health Security, with research by The Economist Intelligence Unit. Available at: $<$ https://www.ghsindex.org/> [Accessed 3 May 2020].

Gopinath, G. (2020). The Great Lockdown: Worst Economic Downturn Since the Great Depression [blog] Available at: <https://blogs.imf.org/2020/o4/14/the-great-lockdownworst-economic-downturn-since-the-great-depression/> [Accessed 3 May 2020].

Grusky, D., Western, B., and Wimer, C. (2011). The Great Recession. New York: Russell Sage.

Gudi, S. K. and Tiwari, K. K. (2020). Preparedness and lessons learned from the novel coronavirus disease. The International Journal of Occupational and Environmental Medicine, $11(2), 108$.

Haffajee, R. and Mello, M. (2020). Thinking Globally, Acting Locally - The U.S. Response to Covid-19. New England Journal of Medicine, 382(22), e75.

Hall, P., Lister, D., and Mercer, D. (2020). Privatised and Unprepared: The NHS Supply Chain [online] London: University of Greenwich and We Own It. Available at: <https:// lowdownnhs.info/wp-content/uploads/2020/05/PrivatisedAndUnprepared-NHSSupply Chain-Report-A4-2-1.pdf> [Accessed 5 June 2020].

Hanage, W. (2020). I'm an epidemiologist. When I heard about Britain's 'herd immunity' coronavirus plan, I thought it was satire. The Guardian, 03-15. Available at: <https://www. theguardian.com/commentisfree $/ 2020 / \mathrm{mar} / 15 /$ epidemiologist-britain-herd-immunitycoronavirus-covid-19> [Accessed May 2020]. 
Vol. 7, No. 1, 9-45.

Hayek, F. (1960). The Constitution of Liberty: The Definitive Edition. London and New York: The University of Chicago Press.

Hays, J. N. (2005). Epidemics and pandemics: their impacts on human history. Santa Barbara, CA: ABC Clio.

Henderson, D. A. (2011). The eradication of smallpox - an overview of the past, present, and future. Vaccine, 29, $\mathrm{D}_{7-\mathrm{D}_{9} .}$

Hobsbawm, E. (1968). Industry and Empire: The Birth of The Industrial Revolution. London: Weidenfeld and Nicolson.

Hoehl, S., Rabenau, H., Berger, A., Kortenbusch, M., Cinatl, J., Bojkova, D., and Neumann, P. (2020). Evidence of SARS-CoV-2 infection in returning travelers from Wuhan, China. New England Journal of Medicine, 382(13), 1278-1280.

Hofstede, G. (1980). Culture's Consequences: International Differences in Work-Related Values. 1st ed. Beverly Hills, CA: Sage Publications.

Horak, S. (2015). Culture or anonymity? Differences in proposer behaviour in Korea and Germany. International Journal of Psychology, 50(5), 397-401.

Horton, R. (2020). Offline: COVID-19 and the NHS-“a national scandal”. The Lancet, 395(10229), 1022.

Hoynes, H., Miller, D. and Schaller, J. (2012). Who Suffers During Recessions? Journal of Economic Perspectives, 26(3), 27-48.

Imrie, R. (1991). Industrial change and local economic fragmentation: The case of Stoke-onTrent. Geoforum, 22(4), 433-453.

International Monetary Fund. (2014). What Is Keynesian Economics? Finance \& Development [online] IMF. Available at: <http://www.imf.org/external/pubs/ft/fandd/2014/og/basics. htm\#author> [Accessed 14 December 2017].

Ioannidis, J. (2020). A fiasco in the making? As the coronavirus pandemic takes hold, we are making decisions without reliable data. STAT News [online] Available at: <https://www. statnews.com/2020/o3/17/a-fiasco-in-the-making-as-the-coronavirus-pandemic-takeshold-we-are-making-decisions-without-reliable-data/> [Accessed 3 May 2020].

Irish, J. (2020). French hospital discovers Covid-19 case from December. Reuters, May 4. Available at: <https://uk.reuters.com/article/us-health-coronavirus-france/after-retesting-samples-french-hospital-discovers-covid-19-case-from-december-idUKKBN22G2oL> [Accessed June 2020].

Islam, N., Ishaq, M., Bukhari, B., and Siddiqui, M. K. (2009). Ai-qanun: Ibn Sina's contribution to the world of medicine. Journal of Central Asian Studies, 18(1), 143-148.

Jackson, G. and Sorge, A. (2012). The trajectory of institutional change in Germany, 19792009. Journal of European Public Policy, 19(8), 1146-1167.

Japan Medical Association. (2020). Current Status and Problems of Intensive Care In Japan During The Spread Of New Coronavirus Infection [online] Japan Medical Association. Available at: <https://www.covid19-jma-medical-expert-meeting.jp/topic/1121> [Accessed 29 May 2020].

Joint Emergency Services Interoperability Principles (JESIP). (2016). Joint Emergency Services Interoperability Principles. JESIP. 
Jones, D. (2014). Masters of The Universe. Princeton: Princeton University Press.

Josifidis, K., Losonc, A., and Supic, N. (2010). Neoliberalism: Befall or respite? Panoeconomicus, 57(1), 101-117.

Jowett, P. (2020). An overview of Germany's response to Covid-19 [blog] Local Government Information Unit (LGIU) Available at: <https://lgiu.org/an-overview-of-germanys-responseto-covid-19/> [Accessed 29 May 2020].

Kim, K. (1991). The Korean Miracle (1962-1980) Revisited: Myths and Realities in Strategy and Development [eBook] Kellogg Institute. Available at: <https://kellogg.nd.edu/sites/ default/files/old_files/documents/166_o.pdf> [Accessed 14 May 2020].

Kim, T., Kwon, H., Lee, J., and Yi, I. (2011). "Mixed Governance” and Welfare in South Korea. Journal of Democracy, 22(3), 120-134.

King, D. and Wood, S. (1999). The Political Economy of Neoliberalism: Britain and the United States in the 1980s. In: H. Kitschelt, P. Lange, G. Marks and J. Stephens, ed., Continuity and Change in Contemporary Capitalism. Cambridge, UK: Cambridge University Press.

Kitschelt, H. and Streeck, W. (2003). From Stability of Stagnation: Germany at the beginning of the twenty-first century. West European Politics, 26(4), 1-34.

Klein, E., Rozansky, K., Gordon., C., Mumm, C., Nishimura, L., Posner, J., Spingarn-Koff, J., and Townsend, K. (2020). Coronavirus Explained [TV Series]. Netflix.

Klein, N. and Peet, R. (2008). The shock doctrine: The rise of disaster capitalism. Human Geography, 1(2), 130-133.

Klein, N. (2008). The Shock Doctrine. London: Penguin.

Kuznets, P. (1985). Government and Economic Strategy in Contemporary South Korea. Pacific Affairs, 58(1), 44.

Lee, J. (2020). How South Korea Flattened the Curve [online] Prospectmagazine.co.uk. Available at: <https://www.prospectmagazine.co.uk/magazine/south-korea-coronavirusflatten-curve-covid-19> [Accessed 19 May 2020].

Lim, E. K., Guk, K., Kim, H., Chung, B. H., and Jung, J. (2015). Simple, rapid detection of influenza $\mathrm{A}\left(\mathrm{H}_{1} \mathrm{~N}_{1}\right)$ viruses using a highly sensitive peptide-based molecular beacon. Chemical Communications, 52(1), 175-178.

Littman, R. J. (2009). The plague of Athens: epidemiology and paleopathology. Mount Sinai Journal of Medicine: A Journal of Translational and Personalized Medicine: A Journal of Translational and Personalized Medicine, 76(5), 456-467.

Loopstra, R., Reeves, A., Taylor-Robinson, D., Barr, B., McKee, M., and Stuckler, D. (2015). Austerity, sanctions, and the rise of food banks in the UK. BMJ, 350, hi775-h1775.

MacLeavy, J. (2011). A 'new politics' of austerity, workfare, and gender? The UK coalition government's welfare reform proposals. Cambridge Journal of Regions, Economy and Society, 4(3), 355-367.

Maizland, L. and Felter, C. (2020). Comparing Six Health-Care Systems in A Pandemic [online] Council on Foreign Relations. Available at: <https://www.cfr.org/backgrounder/ comparing-six-health-care-systems-pandemic $>$ [Accessed 29 May 2020].

Malik, N. (2020). It's no accident Britain and America are the world's biggest coronavirus losers. The Guardian [online] Available at: <https://www.theguardian.com/commentisfree/2020/may/10/anglo-american-coronavirus-crisis> [Accessed 21 May 2020]. 
Vol. 7, No. 1, 9-45.

Marcus, A. and Oransky, I. (2020). The Science of This Pandemic Is Moving at Dangerous Speeds. Wired [online] Available at: <https://www.wired.com/story/the-science-of-thispandemic-is-moving-at-dangerous-speeds/> [Accessed 3 May 2020].

Margaretthatcher.org. (2020). Thatcher, Hayek \& Friedman | Margaret Thatcher Foundation [online] Available at: <https://www.margaretthatcher.org/archive/Hayek.asp> [Accessed 18 May 2020].

Mohan, J. (2002). Planning, Markets and Hospitals. 1st ed. London, UK: Routledge.

Moormann, A. M. (2020). Epidemic to Endemic or Pandemic Infectious Diseases: Commonalities and Distinctions between Malaria, Ebola and COVID19. PEER Liberia, COVID-19 Seminar, on April 22020.

Murphy, J., Jones, J., and Conner, J. (2020). The COVID-19 pandemic: Is it a "Black Swan"? Some risk management challenges in common with chemical process safety. Process Safety Progress, 39(2). Aavailable at: <https://aiche.onlinelibrary.wiley.com/doi/full/10.1002/ prs.12160> [Accessed June 2020].

National Health Service. (2012). Health and Social Care Influenza Pandemic and Response. London, UK: The Department of Health.

NHS England (2017). BOARD PAPER: Emergency Preparedness, Resilience and Response (EPRR). London: NHS ENGLAND.

NHS for Sale. (2020). 50 Examples of NHS Outsourcing Failures - NHS For Sale [online] Available at: <https://www.nhsforsale.info/in-the-press/5o-examples-of-nhs-outsourcingfailures/> [Accessed 5 June 2020].

Noland, M. (2014). Six markets to watch, South Korea: the backwater that boomed. Foreign Affairs, 93(1). Available at:<https://www.foreignaffairs.com/articles/south-korea/2013-12-o6/ six-markets-watch-south-korea> [Accessed April 2020].

O'Hara, M. (2014). Austerity Bites: A Journey to The Sharp End Of Cuts In The UK. Bristol, UK: Policy Press.

Ons.gov.uk. (2020). Deaths Involving COVID-19, England And Wales - Office for National Statistics [online] Available at: <https://www.ons.gov.uk/peoplepopulationandcommunity/birthsdeathsandmarriages/deaths/bulletins/deathsinvolvingcovidıenglandandwales/ deathsoccurringinapril2020> [Accessed 23 May 2020].

Otte, J. (2020). Number of people to die of Covid-19 in UK hospitals passes 20,000. The Guardian, April 25. Available at: <https://www.theguardian.com/world/2020/apr/25/ukcoronavirus-death-toll-passes-grim-milestone-of-20000> [Accessed June 2020].

Our World in Data. (2020). Total Confirmed COVID-19 Deaths Per Million People [online] Available at: <https://ourworldindata.org/grapher/total-covid-deaths-per-million> [Accessed 31 May 2020].

Palley, T. (2005). From Keynesianism to Neoliberalism: Shifting Paradigms in Economics. In: A. Saad-Filho and D. Johnston, ed., Neoliberalism: A Critical Reader. Sidmouth, UK: Chase Publishing, pp. 20-29.

Panda, A. (2020). Chinese Foreign Ministry Spokesperson Implies US Military Brought Coronavirus to Wuhan. The Diplomat, March 13. Available at: <https://thediplomat. com/2020/o3/chinese-foreign-ministry-spokesperson-implies-us-military-brought-coronavirus-to-wuhan/> [Accessed June 2020]. 
Papagrigorakis, M. J., Yapijakis, C., Synodinos, P. N., and Baziotopoulou-Valavani, E. (2006). DNA examination of ancient dental pulp incriminates typhoid fever as a probable cause of the Plague of Athens. International Journal of Infectious Diseases, 10(3), 206-214.

Parodi, E. and Aloisi, S. (2020). Italian scientists investigate possible earlier emergence of coronavirus. Reuters, March 26. Available at: <https://www.reuters.com/article/ushealth-coronavirus-italy-timing/italian-scientists-investigate-possible-earlier-emergenceof-coronavirus-idUSKBN21D2IG> [Accessed May 2020].

Patrick, P. (2020). Japan's Covid success is a mystery. The Spectator [online] Available at: $<$ https://www.spectator.co.uk/article/the-mystery-of-japan-s-covid-success> [Accessed 29 May 2020].

Peck, J. and Tickell, A. (2012). Apparitions of neoliberalism: revisiting 'Jungle law breaks out'. Area, 44(2), 245-249.

Peck, J. (2010). Constructions of Neoliberal Reason. Oxford, UK: Oxford University Press.

Pegg, D. (2020). Covid-19: did the UK government prepare for the wrong kind of pandemic? The Guardian [online] Available at: <https://www.theguardian.com/world/2020/ may/21/did-the-uk-government-prepare-for-the-wrong-kind-of-pandemic\#maincontent> [Accessed 13 May 2020].

Pegg, D. (2020). What does the leaked report tell us about the UK's pandemic preparations? The Guardian [online] Available at: <https://www.theguardian.com/world/2020/apr/24/ preparing-for-pandemic-national-security-risk-assessment-coronavirus> [Accessed 6 June 2020].

Pegg, D. (2020). What was Exercise Cygnus and what did it find? The Guardian [online] Available at: <https://www.theguardian.com/world/2020/may/o7/what-was-exercise-cygnusand-what-did-it-find $>$ [Accessed 15 May 2020].

Pegg, D., Booth, R., and Conn, D. (2020). Revealed: the secret report that gave ministers warning of care home coronavirus crisis. The Guardian [online] Available at: <https://www. theguardian.com/world/2020/may/o7/revealed-the-secret-report-that-gave-ministerswarning-of-care-home-coronavirus-crisis> [Accessed 28 May 2020].

Perry, M. (2020). This Is How America and China are Weaponizing the Coronavirus. The National Interest, April 28. Available at: <https://nationalinterest.org/feature/how-america-and-china-are-weaponizing-coronavirus-148906> [Accessed June 2020].

Peter G Peterson Foundation. (2020). Selected Charts on The Long-Term Fiscal Challenges of The United States [online] New York, USA: The Peter G Peterson Foundation. Available at: <https://www.pgpf.org/sites/default/files/PGPF-Chart-Pack.pdf> [Accessed 2 June 2020].

Petherick, A. (2020). Developing antibody tests for SARS-CoV-2. The Lancet, 395(10230), 1101-1102.

Pierce, J. and Schott, P. (2016). The Surprisingly Swift Decline of US Manufacturing Employment. American Economic Review, 106(7), 1632-1662.

Polanyi, K. (2001). The Great Transformation: The Political and Economic Origins of Our Time. 2nd ed. Boston, MA: Beacon Press.

Pollock, A. M., Price, D., and Liebe, M. (2011). Private finance initiatives during NHS austerity. BMJ, 342, d324. 
Vol. 7, No. 1, 9-45.

Poole, J. C. F. and Holladay, A. J. (1979). Thucydides and the Plague of Athens. The Classical Quarterly, 29(2), 282-300.

Porterfield, C. (2020). The Miraculous 'Mr. P': 101-Year-Old Italian Man Beats Coronavirus. Forbes Inc. [online] Available at: <https://www.forbes.com/sites/carlieporterfield/2020/03/27/the-miraculous-mr-p-101-year-old-italian-man-beats-coronavirus/\#6fic9b5148bc> [Accessed 3 May 2020].

Potter, C. W. (2001). A history of influenza. Journal of applied microbiology, 91(4), 572-579.

Prahalad, C. and Hamel, G. (1990). The Core Competence of the Corporation. Harvard Business Review [online] Available at: <https://hbr.org/1990/05/the-core-competence-ofthe-corporation> [Accessed 3 May 2020].

Public Health England. (2014). Pandemic Influenza Strategic Framework. London, UK: Public Health England.

Qiu, L. and Zhan, C. (2016). China's Global Influence: A Survey through the Lens of International Trade. Pacific Economic Review, 21(1), 45-71.

Quilty-Harper, C. and Liverpool, L. (2020). Covid-19 News: Boris Johnson Admits UK Was Unprepared for Pandemic - The World in News [online] The World in News. Available at: <https://theworldinnews.com/covid-19-news-boris-johnson-admits-uk-was-unpreparedfor-pandemic-4-15335/> [Accessed 27 May 2020].

Radcliffe, S. and Chesak, J. (2020). What Is the Cost of Getting Tested and Treated for the Coronavirus? Healthline [online] Available at: <https://www.healthline.com/health-news/ if-you-get-the-coronavirus-what-will-it-cost-you> [Accessed 8 June 2020].

Ravi, S. and Kapoor, M. (2020). COVID-19 Trends from Germany Show Different Impacts by Gender And Age [online] Brookings. Available at: <https://www.brookings.edu/blog/techtank/2020/o5/o1/covid-19-trends-from-germany-show-different-impacts-by-gender-andage/> [Accessed 23 May 2020].

Rhodes, A., Ferdinande, P., Flaatten, H., Guidet, B., Metnitz, P., and Moreno, R. (2012). The variability of critical care bed numbers in Europe. Intensive Care Medicine, 38(10), 1647-1653.

Ridge, M. (2002). Gone to pot. The Guardian Supplement [online] Available at: <https:// www.theguardian.com/society/2002/may/29/guardiansocietysupplement> [Accessed 13 May 2020].

Rigby, E. (2012). State Resistance to "ObamaCare". The Forum, 10(2). Available at: <https:// www.degruyter.com/view/journals/for/10/2/article-1540-8884.1501.xml.xml?language=en> [Accessed June 2020].

Sabbagh, D. (2020). Matt Hancock urged to publish secret review of pandemic plans. The Guardian [online] Available at: <https://www.theguardian.com/politics/2020/apr/28/matthancock-urged-to-publish-secret-review-of-pandemic-plans> [Accessed 28 May 2020].

Sabbatani, S. and Fiorino, S. (2009). The antonine plague and the decline of the Roman Empire. Le infezioni in medicina: rivista periodica di eziologia, epidemiologia, diagnostica, clinica e terapia delle patologie infettive, 17(4), 261-275.

Scientific Pandemic Influenza Group on Modelling. (2018). SPI-M Modelling Summary. London: Scientific Pandemic Influenza Group. 
Sharma MP, T. and Sunak MP, T. (2020). Coronavirus - Business Support to Launch from Today [online] GOV.UK. Available at: <https://www.gov.uk/government/news/coronavirusbusiness-support-to-launch-from-today> [Accessed 21 May 2020].

Shchelkunov, S. N. (2009). How long ago did smallpox virus emerge? Archives of virology, 154(12), 1865-1871.

Shereen, M., Khan, S., Kazmi, A., Bashir, N., and Siddique, R. (2020). COVID-19 infection: Origin, transmission, and characteristics of human coronaviruses. Journal of Advanced Research, 24, 91-98.

Smith, D. B. (2020). The Pandemic Challenge: End Separate and Unequal Healthcare. The American Journal of the Medical Sciences, 360(2): 109-111.

Sonn, J. (2020). Coronavirus: South Korea's Success in Controlling Disease Is Due to Its Acceptance Of Surveillance [online] The Conversation. Available at: <https://theconversation.com/coronavirus-south-koreas-success-in-controlling-disease-is-due-to-its-acceptance-of-surveillance-134068> [Accessed 15 May 2020].

Spahn, J. (2020). How Germany Contained the Coronavirus | By Jens Spahn - Project Syndicate [online] Project Syndicate. Available at: <https://www.project-syndicate.org/ commentary/how-germany-contained-covid19-by-jens-spahn-2020-05> [Accessed 29 May 2020].

Stanley, L. (2008). Emerging Markets and Financial Globalization. 1st ed. London, UK: Anthem Press.

Stiglitz, J. (2015). Re-Writing the Rules of The America Economy: An Agenda For Growth And Shared Prosperity [online] New York, US: Roosevelt Institute. Available at: <http:// rooseveltinstitute.org/wp-content/uploads/2015/10/Rewriting-the-Rules-Report-FinalSingle-Pages.pdf> [Accessed 12 May 2020].

Stiglitz, J. (2019). People, Power, And Profits: Progressive Capitalism for An Age of Discontent. London: Allen Lane.

Stuckler, D., Reeves, A., Loopstra, R., Karanikolos, M., and McKee, M. (2017). Austerity and health: the impact in the UK and Europe. European Journal of Public Health, 27(suppl_4), 18-21.

STUECK, W. (1986). The Korean War as International History. Diplomatic History, 10(4), 291-309.

Taleb, N. (2008). The Black Swan: The Impact of The Highly Improbable. London: Penguin Books Ltd.

Tárnok, A. (2020). The Cholera Epidemics in Hamburg and What to Learn for COVID-19 (SARS-CoV-2). Cytometry, 97(4), 337.

The Department of Health. (2011). UK Influenza Pandemic Preparedness Strategy. London: Department of Health, Social Services, Public Health (DHSSP).

The Financial Crisis Enquiry Commission. (2011). The Financial Crisis Enquiry Report. Washington, DC: USA Government.

The Independent Scientific Advisory Group for Emergencies (SAGE). (2020). The Independent SAGE Report Of 12Th May 2020 - COVID-19: What Are the Options for the UK? Independent SAGE Report [online] London: The Independent Scientific Advisory Group for Emergencies 
(SAGE). Available at: <https://www.gov.uk/government/groups/scientific-advisory-groupfor-emergencies-sage $>$ [Accessed 20 May 2020].

The New and Emerging Respiratory Virus Threats Advisory Group (NERVTAG). (2019). 2nd Annual Report: January To December 2016. London: NERVTAG.

Tuschke, A. and Luber, M. (2012). Corporate Governance in Germany: Converging Towards Shareholder Value-Orientation or Not So Much? The Convergence of Corporate Governance, pp. 75-92.

Tyler, C. and Gluckman, P. (2020). Coronavirus: governments knew a pandemic was a threat here's why they weren't better prepared. The Conversation, April 28. Available at : <https:// theconversation.com/coronavirus-governments-knew-a-pandemic-was-a-threat-hereswhy-they-werent-better-prepared-136857> [Accessed June 2020].

U.S. Department of Health and Human Services. (2019). Crimson Contagion 2019 Functional Exercise: Draft After-Action Report. Washington: U.S. Department of Health and Human Services.

UK Cabinet Office. (2008). 2008 National Risk Assessment. London: The Cabinet Office.

UK Cabinet Office. (2019). 2019 National Risk Assessment. London: The Cabinet Office.

UK Farming News. (2019). Dairy Farmers' Profits Fall By 5o Percent in Space of Year [online] Farminguk.com. Available at: <https://www.farminguk.com/news/dairy-farmers-profitsfall-by-5o-percent-in-space-of-year_54043.html> [Accessed 8 June 2020].

van Leeuwen, J. (2010). The Domino Effect. American Journal of Physics, 78(7), 721-727.

Wilensky, G. (2012). The Shortfalls of "Obamacare”. New England Journal of Medicine, 367(16), 1479-1481.

Winterburn, T. (2020). At 104 years old an Italian 'Super Gran' survives the Spanish Flu and the Coronavirus. Euro Weekly [online] Available at: <https://www.euroweeklynews. com/2020/04/o6/at-104-years-old-an-italian-super-gran-survives-the-spanish-flu-and-thecoronavirus/> [Accessed 3 May 2020].

World Health Organization. (2014). Germany: Health System Review. Health Systems in Transition [online] Copenhagen: World Health Organization. Available at: <https://apps. who.int/iris/handle/10665/130246> [Accessed 18 May 2020].

World Health Organization. (2015). Republic of Korea: Health System Review. Health Systems in Transition [online] Seoul: World Health Organization. Available at: <https:// apps.who.int/iris/handle/10665/208215> [Accessed 18 May 2020].

World Health Organization. (2015). United Kingdom Health System Review. Health Systems in Transition [online] Copenhagen: World Health Organization. Available at: <https://apps. who.int/iris/handle/10665/208215> [Accessed 18 May 2020].

Worldometers.info. (2020). Population by Country (2020) - Worldometer [online] Available at: <https://www.worldometers.info/world-population/population-by-country/> [Accessed 8 May 2020]. 